\title{
Rating Performance and Bank Business Models: Is There a Change with the 2007-2009 Crisis?
}

\author{
Vincenzo D'Apice ${ }^{1}$ - Giovanni Ferri ${ }^{2}$ (D) \\ Punziana Lacitignola ${ }^{3}$
}

\begin{abstract}
We investigate the relationship between a bank's rating and its business model and hypothesize that relationship changed through the crisis. We use bank ratings by Fitch, Moody's and S\&P's from 2006 to 2009 and proxy the business model via an index given by a banks' traditional income share in total income. In a sample of 241 listed banks from 39 countries, controlling for sovereign ratings and other bank characteristics, we find that banks with higher values of the index had: (1) similar ratings to other banks until 2007; (2) better rating performance through 2008-2009. The evidence supports our hypothesis.
\end{abstract}

Keywords Financial crises · Financial markets · Bank ratings · Ratings · Banks business models

JEL Classification $\mathrm{G} 1 \cdot \mathrm{G} 15 \cdot \mathrm{G} 21 \cdot \mathrm{G} 24$

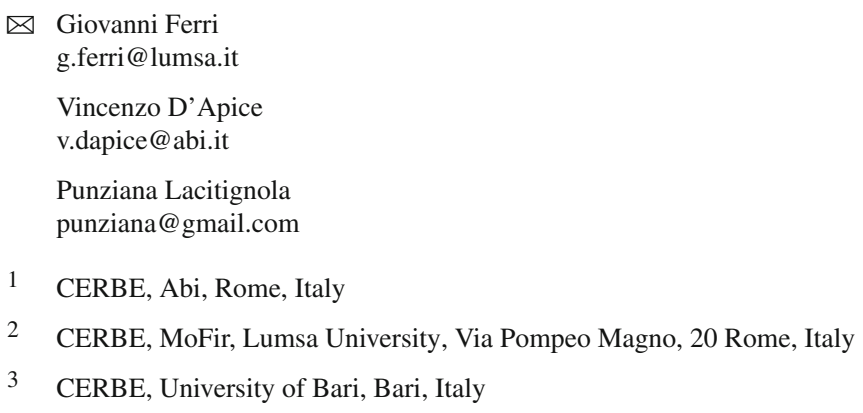




\section{Introduction}

The financial crisis started in 2007 highlighted that transformations in bank business models played a role in lowering lending standards and heightening systemic risk (see, for example, Altunbas et al. 2011; Berndt and Gupta 2009; Bord and Santos 2012; Mian and Sufi 2009; Stiglitz 2010; Financial Services Authority 2009; D’Apice and Ferri 2010). Specifically, many banks moved away from traditional business-gathering deposits to make loans to be held to maturity on their balance sheets, Originate to Hold (OtH) model — to a new market-attuned business model (Originate to Distribute, OtD), where they make loans to be securitized on financial markets. The extent to which banks moved away from their traditional business model may be gauged as a new source of risk (Gennaioli et al. 2012), which the rating agencies might possibly take into account (Salvador et al. 2014a).

Starting from this idea, we investigate whether, after the outbreak of the 20072009 crisis, bank ratings became more related to the bank business model. To do so, focusing on the three major agencies (Fitch, Moody's and S\&P's), we use the level of bank ratings between 2006 and 2009 and an index of how closely each bank kept to the traditional business model. ${ }^{1}$

Specifically, we take two slightly different but complementary approaches via crosssection and panel estimations. In the cross-section, we analyze whether the banks that were more traditional before the crisis had a better rating performance with respect to the other banks between 2006 and $2009 .^{2}$ In a way, in fact, the perception that these banks were less exposed to the financial-market-related risks at the core of the crisis could have persistent favorable effects on their ratings. In the panel estimations, we examine the relationship with the ratings by letting the bank business model change. ${ }^{3}$ Various banks, in fact, decided to change their business model in response to the crisis and this could also affect the way the rating agencies evaluated them.

Overall, both approaches show that banks with a higher share of traditional income over total income exhibited better rating performance in our sample of 241 listed banks from 39 countries.

Thus, even though the experience of the crisis suggests that regulation ought to factor in each bank's business model in assessing its risk exposure (Caprio et al. 2014), market forces - in this case the rating agencies - may have imparted themselves the right incentives to banks. In fact, better ratings favored those banks adhering more closely to the traditional business model.

Our results could be seen at odds with other studies on the relationship between bank business model and risk, finding that also more diversified banks have been more stable in the recent crisis (see, e.g., Altunbas et al. 2011; Köhler 2015). However, our study differs in two main aspects. First, we use the bank rating as measure of risk, whereas

\footnotetext{
1 As explained in Sect. 3, we proxy the business model with the following variable: traditional business index $=$ (net interest income + fees and commissions-dividend income)/operating income.

2 In the cross-section approach, we measure the traditional business index on the 2006 profit and loss accounts.

3 In the panel specification, we measure the traditional business index yearly from 2006 to 2009.
} 
they use the z-score (Köhler 2015) or bank distress proxies (Altunbas et al. 2011). While bank distress regards extreme events only and the z-score captures, by construction, the distance to default as a risk-return combination, rating changes seem more general. A rating change may, in fact, denote a bank undergoing non-extreme events or its performance being affected by items-e.g., liquidity-disregarded by the z-score. Second, as suggested by De Young and Torna (2013), we consider fees and commissions related to traditional operations as traditional income; whereas they include this source of revenue in the non-interest income (Altunbas et al. 2011; Köhler 2015).

In addition, a further differentiation of our paper descends from the fact that we take only listed banks from 39 countries, while they use also unlisted banks (Köhler 2015) or focus only on European banks (Altunbas et al. 2011; Köhler 2015). On one hand, considering listed banks only ensures that there will likely be at least two ratings for each bank. On the other, however, this choice reduces the number of banks in our sample.

In the rest of the paper, Sect. 2 draws a survey of the literature. Section 3 outlines the data used. Section 4 reports the methodology, discusses the main results of our econometric analysis and describes various robustness checks. Finally, Sect. 5 concludes and debates the implications of our findings.

\section{Literature Review}

In the decades up to the Great Financial Crisis, financial deregulation/innovation, heightened competition and the deepening of financial markets led most banks to move out of their traditional banking services. In the composition of bank profit and loss accounts, this implied a rise of non-interest revenues and a fall in interest margins. Also, increasing reliance on non-interest income was seen as a means to both strengthen and smooth bank profitability. Based on the belief that non-interest and net interest incomes be negatively or imperfectly correlated, non-traditional activities were judged more stable (or less cyclical) income than loan-based earnings and a way to reduce overall risk via diversification. Hence, diversifying banks' product mix was thought to lower their profit volatility and reduce their risk.

Various papers investigated the impact of diversification on bank cost structure and its benefits in terms of economies of scale, joint production and X-efficiencies. The typical finding is that higher income and lower risk are achieved in the US Bank Holding Companies diversifying into non-traditional business, like insurance and/or asset management (Herring and Santomero 1990; Gallo et al. 1996; Berger and Mester 1997; Harker and Zenios 2000).

However, the credence that more diversified income sources cause-e.g., via higher non-interest income shares-lower bank profit volatility was rejected for the US (Roland 1997; De Young and Roland 1999). These authors attribute their results to the fact that traditional relationship lending tends to smoothen income as information asymmetries and switching costs lower the probability that borrowers and/or lenders shut down customer relationships. These market imperfections would make borrowers less inclined to search for better terms in the credit market than they do in more standard trading. Moreover, banks moving into new activities undergo large fixed investments (especially in IT). This interferes with cost cutting strategies, dents the 
extent of economies of scale and scope and raises operational risk that has become costly with Basel II (Berger and Mester 1999). In addition, Stiroh (2004, 2006) shows that the lower volatility of banks' net operating revenue comes from lessened volatility of net interest income, and not from non-interest income, which is quite volatile and increasingly correlated with net interest income.

The situation is similar in Europe. Staikouras et al. (2000) and Staikouras and Wood (2003) show that diversification gives a limited contribution to banks' profit stabilization and risk reduction. However, market participants may perceive diversified banks more protected than specialized competitors against deteriorations in market conditions (Baele et al. 2004).

In turn, the transformation of the bank business model from the traditional OtH into the new OtD may have heightened systemic risk since the severance of bank-borrower relationships implied by the second model allows borrowers' suboptimal investment/decisions, lacking the discipline of banks' screening and monitoring (Berndt and Gupta 2009).

In theory, the OtD model implies a simple business reconfiguration with banks increasingly operating as originators and packagers of credit risks ultimately borne by others (Llewellyn 1999). When it functions correctly-i.e., when banks focus on the origination, servicing and monitoring of loans, following the competitive advantage due to their specialization - the OtD may distribute risks widely and efficiently while diversifying banks' revenue stream (BIS 2008). However, the potential problems of a widely implemented OtD model were less clear. In particular, the OtD model suffered from agency problems, coupled with a tendency to lower underwriting and transparency standards (Pagano and Volpin 2012).

Being the originated loans quickly dismissed from the originators' books and the related risks distributed to market participants, originators had all incentives to boost loan volumes and none to screen and monitor loan quality. Those at the beginning of the loan chain (typically the mortgage brokers) were lured by originating fees and focused on volume generation. Banks, at the center of the securitization process, focused on loan repackaging and on the profitable distribution of the securitized assets while disregarding underlying assets' quality and liquidity commitments towards their special purpose vehicles. On their part, poorly regulated investment banks pushed commercial banks in their quest for creating new securities. In turn, the rating agencies underestimated the risks of structured assets by: (1) overlooking how systemic liquidity problems would depress market valuations; (2) failing to see how the passage from OtH to OtD had lowered credit standards; (3) venturing into rating extremely complex structured products by "marking them to model" on the basis of too rosy assumptions (Benmelech and Dlugosz 2009; Skreta and Veldkamp 2009); (4) sometimes undergoing conflicts of interest by consulting in the structuring process of the products they were to rate (Coval et al. 2009). Finally, those at the end of the loan chain, investors (including banks), underplayed the asset quality problem, overly trusting the due diligence of originators and packagers and the reliability of the rating agencies' judgments.

As the crisis unfolded revealing the faults of a degenerated OtD model, the assumption that bank revenues should be diversified away via more finance-related activities was increasingly questioned. A number of studies found that banks performing tra- 
ditional intermediation activities were either perceived by the market as being less risky (stock prices less sensitive to fluctuations in the stock market index) or less prone to risk-taking (Mercieca et al. 2007; Baele et al. 2007; De Nicolo et al. 2004).

Drawing on a large set of listed banks from Europe, the USA and Japan Bongini et al. (2009) notice that smaller-sized banks suffered less than larger banks in conjunction with the Great Crisis and ask whether there was a "small-bank" anomaly analogous to the classic small firm effect. They conclude that, in fact, there was also a generalized market reassessment of the bank business model. By an event study methodology focusing on September 29, 2008-the day in which the initial rejection by Congress of the Paulson Plan provoked a true worldwide banking panic and led the VIX (the main index measuring equity market volatility) to its highest level in 6 years - they find that banks that had kept closer to the OtH model (with a higher net interest income/operating income ratio) had less negative abnormal returns.

DeJonghe (2010) shows that non-interest income-intensive banks have higher tail betas and as such are more sensitive than traditional banks to extreme market and macro-economic swings. However, using the net interest income/operating income ratio to proxy for banks' adherence to the traditional business model may not be entirely satisfactory because even for traditional business there has been a move over time from interest to fee income. Accordingly, it would be desirable to employ a measure encompassing both net interest income and the related fee income. The approach taken by De Young and Torna (2013) seems promising. Starting from the general tenet held by researchers that the revenues from fee-based activities are more volatile than those from traditional interest-based (loans and deposits) activities, they test whether non-interest income was a determinant in the hundreds of U.S. commercial bank failures during the crisis. Interestingly, they separate noninterest income into three categories: fee income from traditional banking activities like deposit accounts and lines of credit; fee-for-service income from nontraditional activities like brokerage and insurance, and stakeholder income from nontraditional activities against banks' own asset investment. They find that fee-for-service income significantly and substantially reduced the probability that healthy banks failed or became financially distressed, while stakeholder income significantly and substantially increased the probability that distressed banks failed. On this basis, the authors claim that the risk-return characteristics of non-interest income vary in idiosyncratic ways that were not recognized or accounted for in prior research and suggest that bank capital charges should be larger, and supervisory responses at distressed banks should be prompter, for banks that engage in what they define as stakeholder activities.

Finally, close to our paper, Ferri et al. (2014) study rating performance of European banks across ownership/organizational structures. They compare "shareholder value" (profit maximizing) banks vs. "stakeholder value" (maximizing a wider objective, not just profit) banks and find that the rating performance between end 2006 and end 2011 was somewhat better for the latter banks. 


\section{Data}

Our data collection takes all listed banks in Bankscope at the end of 2006 in America, Europe and Asia. We drop banks for any of the following reasons: ${ }^{4}$ (1) total 2006 assets lower than $€ 1$ billion; (2) no deposit financing; (3) subsidiaries of other banks in the sample; (4) without bank rating from at least one of the three main agencies. The resulting sample features 241 banks from 39 countries. $^{5}$

First, we collect the end-of-year ratings issued by the three rating agencies from 2006 to 2009 from Bankscope and Reuters (see Table 1 for data sources and variables definitions). We choose this sample period since we want to investigate bank rating performance after the outbreak of the Great Financial Crisis, but before the Euro Sovereign crisis, whose starting date can be set in May 2010, with the bailout of Greece. We focus on senior unsecured bank ratings. ${ }^{6}$ Based on each bank's nationality we also collect its sovereign rating.

Each rating is converted into a numerical value based on the usual standards. ${ }^{7}$ For each bank and sovereign we calculate the difference between the 2009 and 2006 ratings. To take account of the fact that some banks and sovereigns have ratings issued by more than one rating agency (sample heterogeneity), we consider also the mean bank rating calculated as the simple mean of the ratings issued by the three agencies. During the 2007-2009 crisis, we find a mean bank rating variation of -0.27 points; with a minimum of -16 and a maximum of +2 points (see Table 2 for summary statistics). Fitch and S\&P's bank ratings show a mean variation of -0.5 ; whereas Moody's bank ratings exhibit a positive variation of 0.15 . As to sovereign ratings, the mean variation is -0.04 , with a minimum of -2.67 and a maximum of 2.33 points. Fitch and S\&P's sovereign ratings show almost no variation; whereas Moody's rating exhibits a variation of -0.16 .

Next, we collect data on banks' balance sheet and income characteristics from Bankscope and Reuters. To test the role of the business model in bank rating variations over 2006-2009, we calculate a traditional income ratio (trad_inc). The numerator of this ratio is equal to net interest income plus fees and commissions minus dividend income. The denominator is equal to operating income. With regard to the numerator,

\footnotetext{
4 Even though we are aware that our sample of banks may turn out smaller than that in other studies (e.g., Salvador et al. 2014b) due to the requirements we place for inclusion, we believe our database is large enough to ensure generality of the results.

5 Argentina, Australia, Austria, Belgium, Brazil, Canada, Chile, China, Colombia, Cyprus, Denmark, Ecuador, France, Germany, Greece, Hungary, India, Indonesia, Ireland, Italy, Japan, Malaysia, Norway, Philippines, Poland, Portugal, Republic of Korea, Romania, Russian Federation, Singapore, Slovenia, Spain, Sweden, Switzerland, Thailand, Turkey, United Kingdom, USA, Venezuela.

6 When this rating is not available, we take the long-term rating. Fitch and Moody's issue also ratings assigned to the bank as a standalone business-i.e., net of external support, typically a public bailout. However, choosing these ratings would discard S\&P's assessments and reduce our observations. Thus, we opted for the senior unsecured bank ratings but, of course, we control for the sovereign ratings.

7 We apply the following scales for S\&P's and Fitch and (in parenthesis) for Moody's. $\mathrm{AAA}(\mathrm{Aaa})=21 ; \mathrm{AA}+(\mathrm{Aa} 1)=20 ; \mathrm{AA}(\mathrm{Aa} 2)=19 ; \mathrm{AA}-(\mathrm{Aa} 3)=18 ; \mathrm{A}+(\mathrm{A} 1)=17 ; \mathrm{A}(\mathrm{A} 2)=16 ; \mathrm{A}-(\mathrm{A} 3)=15$; $\mathrm{BBB}+(\mathrm{Baa} 1)=14 ; \mathrm{BBB}(\mathrm{Baa} 2)=13 ; \mathrm{BBB}-(\mathrm{Baa} 3)=12 ; \mathrm{BB}+(\mathrm{Ba} 1)=11 ; \mathrm{BB}(\mathrm{Ba} 2)=10 ; \mathrm{BB}-(\mathrm{Ba} 3)=$ 9; $\mathrm{B}+(\mathrm{B} 1)=8 ; \mathrm{B}(\mathrm{B} 2)=7 ; \mathrm{B}-(\mathrm{B} 3)=6 ; \mathrm{CCC}+(\mathrm{Caa} 1)=5 ; \mathrm{CCC}(\mathrm{Ca} 2)=4 ; \mathrm{CCC}-(\mathrm{Caa} 3)=3 ; \mathrm{CC}(\mathrm{Ca})=2$; $\mathrm{C}(\mathrm{C})=1 ; \mathrm{D}(\mathrm{D})=0$.
} 
Table 1 Data sources and variables definitions

\begin{tabular}{|c|c|c|c|}
\hline Variable & Symbol & Source & Description \\
\hline \multicolumn{4}{|l|}{ Bank rating } \\
\hline Bank Rat.CRAs & b_rat_cra & Bankscope-Reuters & $\begin{array}{l}\text { Mean of the numeric value of bank } \\
\text { rating of the three agencies }\end{array}$ \\
\hline Bank Rat.Fitch & b_rat_fit & Bankscope-Reuters & $\begin{array}{l}\text { Numeric value of bank rating issued } \\
\text { by Fitch }\end{array}$ \\
\hline Bank Rat.Moodys & b_rat_mod & Bankscope-Reuters & $\begin{array}{l}\text { Numeric value of bank rating issued } \\
\text { by Moody's }\end{array}$ \\
\hline Bank Rat. S\&P & b_rat_sp & Bankscope-Reuters & $\begin{array}{l}\text { Numeric value of bank rating issued } \\
\text { by S\&P }\end{array}$ \\
\hline $\begin{array}{l}\text { Bank Rat. CRAs } \\
\text { Dif. 09-06 }\end{array}$ & b_rat_cra_dif & Bankscope-Reuters & $\begin{array}{l}\text { Mean bank rating issued by the three } \\
\text { agencies variation } 2009-2006\end{array}$ \\
\hline $\begin{array}{l}\text { Bank Rat. Fitch } \\
\text { Dif. 09-06 }\end{array}$ & b_rat_fit_dif & Bankscope-Reuters & $\begin{array}{l}\text { Fitch bank rating variation between } \\
2009 \text { and } 2006\end{array}$ \\
\hline $\begin{array}{l}\text { Bank Rat. Mood. } \\
\text { Dif. 09-06 }\end{array}$ & b_rat_mod_dif & Bankscope-Reuters & $\begin{array}{l}\text { Moody's bank rating variation } \\
\text { between } 2009 \text { and } 2006\end{array}$ \\
\hline $\begin{array}{l}\text { Bank Rat. S\&P } \\
\text { Dif. 09-06 }\end{array}$ & b_rat_sp_dif & Bankscope-Reuters & $\begin{array}{l}\text { S\&P bank rating variation between } \\
2009 \text { and } 2006\end{array}$ \\
\hline \multicolumn{4}{|l|}{ Sovereign rating } \\
\hline Sov. Rat. CRAs & s_rat_cra & Bankscope-Reuters & $\begin{array}{l}\text { Mean of the numeric value of } \\
\text { sovereign rating of the three } \\
\text { agencies }\end{array}$ \\
\hline Sov. Rat. Fitch & s_rat_fit & Bankscope-Reuters & $\begin{array}{l}\text { Numeric value of sovereign rating } \\
\text { issued by Fitch }\end{array}$ \\
\hline Sov. Rat. Moodys & s_rat_mod & Bankscope-Reuters & $\begin{array}{l}\text { Numeric value of sovereign rating } \\
\text { issued by Moody's }\end{array}$ \\
\hline Sov. Rat. S\&P & s_rat_sp & Bankscope-Reuters & $\begin{array}{l}\text { Numeric value of sovereign rating } \\
\text { issued by } S \& P\end{array}$ \\
\hline $\begin{array}{l}\text { Sov. Rat. CRAs } \\
\text { Dif. 09-06 }\end{array}$ & s_rat_cra_dif & Bankscope-Reuters & $\begin{array}{l}\text { Mean sovereign rating of the three } \\
\text { agencies variation 2009-2006 }\end{array}$ \\
\hline $\begin{array}{l}\text { Sov. Rat. Fitch } \\
\text { Dif. 09-06 }\end{array}$ & s_rat_fit_dif & Bankscope-Reuters & $\begin{array}{l}\text { Fitch sovereign rating variation } \\
\text { between } 2009 \text { and } 2006\end{array}$ \\
\hline $\begin{array}{l}\text { Sov. Rat. Moodys } \\
\text { Dif. 09-06 }\end{array}$ & s_rat_mod_dif & Bankscope-Reuters & $\begin{array}{l}\text { Moody's sovereign rating variation } \\
\text { between } 2009 \text { and } 2006\end{array}$ \\
\hline $\begin{array}{l}\text { Sov. Rat. S\&P } \\
\text { Dif. 09-06 }\end{array}$ & s_rat_sp_dif & Bankscope-Reuters & $\begin{array}{l}\text { S\&P sovereign rating variation } \\
\text { between } 2009 \text { and } 2006\end{array}$ \\
\hline \multicolumn{4}{|l|}{ Buiness model (\%) } \\
\hline $\begin{array}{l}\text { Traditional } \\
\text { income ratio }\end{array}$ & trad_inc & Bankscope-Reuters & $\begin{array}{l}\text { (Net interest income }+ \text { fees and } \\
\text { commissions } / \text { Op. income }\end{array}$ \\
\hline $\begin{array}{l}\text { Net interest } \\
\text { margin/Op. } \\
\text { income }\end{array}$ & niroi & Bankscope & $\begin{array}{l}\text { Net interest income/operational } \\
\text { income }\end{array}$ \\
\hline $\begin{array}{l}\text { Total loans/T.A. } \\
\text { Capital (\%) }\end{array}$ & lo_ta & Bankscope & Loans to private sector/total assets \\
\hline Equity/tot. assets & eq_ta & Bankscope & Equity/total assets \\
\hline
\end{tabular}


Table 1 continued

\begin{tabular}{|c|c|c|c|}
\hline Variable & Symbol & Source & Description \\
\hline $\begin{array}{l}\text { Tangible com. } \\
\text { Eq./T.A. }\end{array}$ & tce_ta & Bankscope & $\begin{array}{l}\text { Tangible common equity/tangible } \\
\text { assets }\end{array}$ \\
\hline \multicolumn{4}{|l|}{ Asset quality (\%) } \\
\hline NPL & $\mathrm{npl}$ & Bankscope & Impaired loans (NPLs)/gross loans \\
\hline $\begin{array}{l}\text { Loans. imp. } \\
\text { charge/av. lns }\end{array}$ & charge & Bankscope & $\begin{array}{l}\text { Loan impairment charges/average } \\
\text { gross loans }\end{array}$ \\
\hline \multicolumn{4}{|l|}{ Management (\%) } \\
\hline Cost-income & cost_inc & Bankscope & Cost to income ratio \\
\hline $\begin{array}{l}\text { Non-int. Exp./Gr. } \\
\text { revenues }\end{array}$ & cost_rev & Bankscope & Non-interest expense/gross revenues \\
\hline \multicolumn{4}{|l|}{ Earnings (\%) } \\
\hline Roe & roe & Bankscope & Net income/average total equity \\
\hline Roa & roa & Bankscope & Net income/average total assets \\
\hline \multicolumn{4}{|l|}{ Liquidity (\%) } \\
\hline Liquidity & liq & Bankscope & Liquid assets/cust. \& ST funding \\
\hline Liquidity 2 & liq2 & Bankscope & Liquid assets/tot. Dep. \& Bor. \\
\hline \multicolumn{4}{|l|}{ Size $(\log )$} \\
\hline Size & size & Bankscope & Natural log of total assets \\
\hline
\end{tabular}

This table presents the names of all the variables employed in our empirical analysis. It also includes the data sources as well as a brief description of how the variables have been constructed

we use also fees and commissions as, although the primary source of income for commercial banks is net interest income, they also generate income from money transfer fees, late fees, check clearing fees, and other fees and commissions. With regard to the denominator, operating income is the sum of net interest income and non-interest income. In turn, non-interest income is the sum of the following items: (1) net gains (losses) on trading and derivatives; (2) net gains (losses) on securities; (3) net gains (losses) on assets at fair value; (4) net insurance income; (5) fees and commissions; (6) other operating income..$^{8,9}$ Thus, the proxy trad_inc discriminates those banks that rely more on interest income as well as fees and commissions as a source of profitability. The higher the ratio, the more the bank is tied to the traditional model (OtH). ${ }^{10}$ In our sample, the mean value of trad_inc is $87.37 \%$, with a standard deviation of 15.24. The range of this index goes from 40.1 to $156.2 \%$ (Table 2).

As other explanatory variables of bank ratings, we consider financial ratios for each of the following areas: Capital adequacy, Asset quality, Management, Earnings, and Liquidity (CAMEL). We use two different ratios to capture banks' capital adequacy:

\footnotetext{
8 This item includes any other income earned from operating activities that cannot be allocated to the above categories (e.g. rental income, income from investment properties, gains on sale of loans \& receivables).

9 The index could be higher than $100 \%$ as the non-interest income (in the denominator) includes gains or losses. Thus, in some cases, when losses are higher that gains, the denominator is lower than the numerator.

10 We winsorize all financial ratios at the 1 and $99 \%$ levels.
} 
Table 2 Summary statistics

\begin{tabular}{|c|c|c|c|c|c|}
\hline Variable & $\mathrm{N}$ & Mean & $\mathrm{SD}$ & Min & Max \\
\hline \multicolumn{6}{|l|}{ Bank rating } \\
\hline Bank rating CRAs Dif. 09-06 & 241 & -0.27 & 1.94 & -16 & 2 \\
\hline Bank rating Fitch Dif. 09-06 & 178 & -0.54 & 2.08 & -15 & 4 \\
\hline Bank rating Moodys Dif. 09-06 & 169 & 0.15 & 1.9 & -8 & 3 \\
\hline Bank rating S\&P Dif. 09-06 & 145 & -0.5 & 1.91 & -16 & 2 \\
\hline Bank rating CRAs & 964 & 14.39 & 3.28 & 0 & 20 \\
\hline Bank rating Fitch & 718 & 14.33 & 3.06 & 0 & 21 \\
\hline Bank rating Moodys & 690 & 15.34 & 3.4 & 6 & 21 \\
\hline Bank rating $\mathrm{S} \& \mathrm{P}$ & 580 & 14.75 & 2.85 & 0 & 19 \\
\hline \multicolumn{6}{|l|}{ Sovereign rating } \\
\hline Sov. rating CRAs Dif. 09-06 & 241 & -0.04 & 0.72 & -2.67 & 2.33 \\
\hline Sov. rating Fitch Dif. 09-06 & 241 & -0.02 & 1.06 & -6 & 2 \\
\hline Sov. rating Moodys Dif. 09-06 & 234 & -0.16 & 0.87 & -3 & 2 \\
\hline Sov. rating S\&P Dif. 09-06 & 241 & 0.01 & 0.84 & -2 & 3 \\
\hline Sov. rating CRAs & 964 & 17.99 & 3.93 & 3.67 & 21 \\
\hline Sov. rating Fitch & 963 & 17.94 & 3.96 & 0 & 21 \\
\hline Sov. rating Moodys & 959 & 18.03 & 4.18 & 2 & 21 \\
\hline Sov. rating $\mathrm{S} \& \mathrm{P}$ & 964 & 18.03 & 3.74 & 5 & 21 \\
\hline \multicolumn{6}{|l|}{ Buiness model (\%) } \\
\hline Traditional income ratio & 964 & 87.37 & 15.24 & 40.1 & 156.2 \\
\hline Niroi & 964 & 67 & 17.64 & 5.9 & 121.4 \\
\hline Total loans/T.A. & 956 & 65.73 & 15.32 & 5.25 & 90.84 \\
\hline \multicolumn{6}{|l|}{ Capital (\%) } \\
\hline Equity/tot. assets & 964 & 7.71 & 3.65 & 0.91 & 24.31 \\
\hline Tangible common equity/tangible assets & 964 & 6.49 & 3.52 & 0.19 & 23.06 \\
\hline \multicolumn{6}{|l|}{ Asset quality (\%) } \\
\hline NPL & 964 & 2.83 & 3.03 & 0 & 16.06 \\
\hline Loans. imp. charge/av. loans & 964 & 0.95 & 1.17 & -0.15 & 5.99 \\
\hline \multicolumn{6}{|l|}{ Management (\%) } \\
\hline Cost-income & 964 & 59.88 & 18.73 & 27.54 & 162.05 \\
\hline Non-interest expense/Gr. revenues & 962 & 59.45 & 17.15 & 26.45 & 151.89 \\
\hline \multicolumn{6}{|l|}{ Earnings (\%) } \\
\hline Roe & 964 & 9.3 & 13.91 & -58.2 & 32.14 \\
\hline Roa & 964 & 0.79 & 0.95 & -3.04 & 3.55 \\
\hline \multicolumn{6}{|l|}{ Liquidity (\%) } \\
\hline Liquid assets/cust \& ST funding & 964 & 20.97 & 19.11 & 1.27 & 104.96 \\
\hline Liquid assets/tot. Dep. \& Bor. & 964 & 16.46 & 13.19 & 0.69 & 69.31 \\
\hline \multicolumn{6}{|l|}{ Size $(\log )$} \\
\hline Size & 964 & 10.38 & 1.68 & 6.96 & 14.77 \\
\hline
\end{tabular}


Table 2 continued

\begin{tabular}{lll}
\hline Variables & $\begin{array}{l}\text { trad_inc }>\text { median } \\
\text { Mean }\end{array}$ & $\begin{array}{l}\text { trad_inc }<=\text { median } \\
\text { Mean }\end{array}$ \\
\hline Bank rating CRAs Dif. 09-06 & 0.10 & $-0.53 * * *$ \\
Sov. rating CRAs Dif. 09-06 & -0.03 & -0.05 \\
Bank rating CRAs & 14.36 & 14.42 \\
Sov. rating CRAs & 17.88 & 18.11 \\
Traditional income ratio & 97.78 & $77.01 * * *$ \\
Equity/tot. assets & 7.56 & 7.86 \\
NPL & 2.96 & $2.69 *$ \\
Cost-income & 60.59 & 59.17 \\
Roe & 7.57 & $11.02 * * *$ \\
Liquidity & 17.33 & $24.59 * * *$ \\
Size & 10.28 & $10.49 * *$ \\
\hline
\end{tabular}

This table presents the summary statistics of the variables used in our paper (see Sect. 3 and Table 1 for further details)

$*$, ** and $* * *$ Indicate statistical significance at the 10,5 and $1 \%$ levels respectively of a two-tails t-test for difference in means

(1) $e q \_t a$, the ratio of equity to total assets, and (2) $t c e \_t a$, the ratio of tangible equity to tangible assets. The first ratio indicates the relative proportion of equity used to finance a company's assets; the other is a ratio that capital markets paid much attention to during the crisis (see Acharya et al. 2009). The sample average eq_ta is $7.71 \%$ while the average tce_ta is $6.49 \%$. Everything else being equal, we would expect the rating performance of banks during the crisis to be positively related to capital ratios, because a bank with more capital would suffer less from the debt overhang problem (Myers 1977). To capture banks' asset quality we use two different measures: (1) npl, the ratio of impaired loans to gross loans, and (2) charge, the ratio of loan impairment charges to average gross loans. Sample averages are $2.83 \%$ for $n p l$ and $0.95 \%$ for charge. We expect that banks with higher asset quality performed better. To capture management abilities we use two different measures: (1) cost_inc, the cost to income ratio, and (2) cost_rev, the ratio of non-interest expenses to gross revenues. Sample averages are $59.88 \%$ for cost-inc and $59.45 \%$ for cost_rev. We expect that banks with a lower level of these two ratios have a better rating performance during the crisis, since they have more flexibility to respond to adverse shocks. We measure bank profitability using two variables: (1) roe, the ratio of net income to average total equity, and (2) roa, the ratio of net income to average total assets. Sample averages are $9.3 \%$ for roe and $0.79 \%$ for roa. We expect a positive effect of roa on bank rating performance, whereas the effect of roe is uncertain, as the level of leverage greatly influences this ratio. We capture bank liquidity with two ratios: (1) liq, the ratio of liquid assets to customers and short-term funding, and (2) liq2, the ratio of liquid assets to total deposits and borrowing funding. Sample averages are $20.97 \%$ for $l i q$ and $16.46 \%$ for liq2. We expect a positive effect of liquidity on bank rating performance as more liquid banks 
have fewer difficulties in a crisis of the type we are analyzing. Finally, we use the natural log of total assets (size) to take bank size into account.

Given the importance of trad_inc for our analysis, it is useful to consider whether being "traditional" associates with other differences in terms of our CAMEL variables. The lower part of Table 2 presents a sample split contrasting the banks with above median trad_inc to the others. The first two rows refer to the cross-section 2006-2009, while the others refer to the whole panel. The first row confirms that on average the change in the bank rating was negative for the non-traditional banks whereas it was slightly positive for traditional banks. The second row suggests that the slight drop in Sovereign ratings of the countries the banks belong to does not seem to explain the different behavior of the ratings for traditional vs. non-traditional banks. Regarding the panel ratings (rows three and four) differences do not appear appreciable. The traditional income ratio, as expected, is significantly larger for the "traditional" group. Differences are insignificant for Equity/Tot. Assets and Cost-Income. On the contrary, for "traditional" banks Roe, Liquidity, and Size are significantly lower while NPL are significantly higher.

\section{Methodology and Empirical Findings}

\subsection{Cross-Section Models}

We start by checking whether our traditional banking proxy was related to bank ratings in the end of 2006 cross-sections. That is done estimating the following OLS models: ${ }^{11}$

$$
\begin{aligned}
\text { b_rat_cra } i, 2006= & \alpha+\beta_{1} \text { s_rat_cra }{ }_{i, 2006}+\beta_{2} \text { trad_inc }_{i, 2006}+\beta_{3} \text { eq_ta } \\
& +\beta_{4} \text { npl }_{i, 2006}+\beta_{5} \text { cost_inc }{ }_{i, 2006}+\beta_{6} \text { roe }_{i, 2006}+\beta_{7} \text { liq }_{i, 2006} \\
& +\beta_{8} \operatorname{size}_{i, 2006}+\varepsilon_{i}
\end{aligned}
$$

where for each bank $i, b \_r a t \_c r a$ and $s \_r a t \_c r a$ are, respectively, the relevant bank's rating and the sovereign rating for the country in which bank $i$ is headquartered. We run four versions of [1]: one where the ratings are taken as means across the three agencies and an additional one for each of Fitch, Moody's and S\&P's.

For the specification on the means we find that sovereign ratings have a positive and statistically significant impact on bank ratings in 2006 (Table 3, column 1). This was expected due to the well known sovereign "ceiling effect" (Borensztein et al. 2013; Ferri et al. 2001; Nickell et al. 2000). Also, in line with Caporale et al. (2012), better capitalized, more efficient, more liquid and bigger banks have higher ratings while traditional income, profitability and NPLs have no impact.

Analogous results attain for the regressions on data for Fitch (Table 3, column 2), Moody's (column 3) and S\&P's (column 4). In particular, traditional income is always insignificant.

To investigate whether an appreciation for traditional banking emerged after the outbreak of the crisis, we use changes in bank ratings between 2006 and 2009 and

11 All the regressions are run with heteroschedasticity-robust standard errors. 
Table 3 Effects of bank business models on bank rating: OLS estimates on 2006 bank ratings

\begin{tabular}{|c|c|c|c|c|}
\hline & $\begin{array}{l}\text { Model 1.a b/se } \\
\text { Bank rating } \\
\text { CRAs } 2006\end{array}$ & $\begin{array}{l}\text { Model } 1 . \mathrm{b} \text { b/se } \\
\text { Bank rating } \\
\text { Fitch } 2006\end{array}$ & $\begin{array}{l}\text { Model 1.c b/se } \\
\text { Bank rating } \\
\text { Moody's } 2006\end{array}$ & $\begin{array}{l}\text { Model 1.d b/se } \\
\text { Bank rating } \\
\text { S\&P } 2006\end{array}$ \\
\hline $\begin{array}{l}\text { Sov. rating } \\
\text { CRAs } 2006\end{array}$ & $\begin{array}{l}0.5979 * * * \\
0.0338\end{array}$ & & & \\
\hline $\begin{array}{l}\text { Traditional } \\
\text { income ratio } \\
2006\end{array}$ & 0.0102 & 0.0107 & 0.0131 & 0.0117 \\
\hline $\begin{array}{l}\text { Equity/tot. } \\
\text { assets } 2006\end{array}$ & $\begin{array}{l}0.0813 * * \\
0.0403\end{array}$ & $\begin{array}{l}0.0082 \\
0.0439\end{array}$ & $\begin{array}{l}0.1249 * * \\
0.052\end{array}$ & $\begin{array}{l}0.0452 \\
0.0439\end{array}$ \\
\hline NPL 2006 & $\begin{array}{l}0.0669 \\
0.0612\end{array}$ & $\begin{array}{l}0.1189 * \\
0.0637\end{array}$ & $\begin{array}{l}0.063 \\
0.0603\end{array}$ & $\begin{array}{l}-0.1197 * \\
0.0722\end{array}$ \\
\hline $\begin{array}{l}\text { Cost-income } \\
2006\end{array}$ & $\begin{array}{l}-0.0302 * * \\
0.0136\end{array}$ & $\begin{array}{l}-0.0217 \\
0.0132\end{array}$ & $\begin{array}{l}-0.0412 * * * \\
0.0154\end{array}$ & $\begin{array}{l}-0.0427 * * * \\
0.0153\end{array}$ \\
\hline Roe 2006 & $\begin{array}{l}-0.0328 \\
0.0288\end{array}$ & $\begin{array}{l}0.03 \\
0.0207\end{array}$ & $\begin{array}{l}-0.0478 \\
0.0302\end{array}$ & $\begin{array}{l}-0.0647 * * * \\
0.0201\end{array}$ \\
\hline Liquidity 2006 & $\begin{array}{l}0.0156^{* *} \\
0.0061\end{array}$ & $\begin{array}{l}0.0111 * \\
0.0056\end{array}$ & $\begin{array}{l}0.0184 * * \\
0.008\end{array}$ & $\begin{array}{l}0.0235^{* * * *} \\
0.0063\end{array}$ \\
\hline Size 2006 & $\begin{array}{l}0.5720 * * * \\
0.0765\end{array}$ & $\begin{array}{l}0.6682 * * * \\
0.0782\end{array}$ & $\begin{array}{l}0.4535 * * * \\
0.0949\end{array}$ & $\begin{array}{l}0.5004 * * * \\
0.1224\end{array}$ \\
\hline $\begin{array}{l}\text { Sov. rating } \\
\text { Fitch } 2006\end{array}$ & & $\begin{array}{l}0.5011 * * * \\
0.0319\end{array}$ & & \\
\hline $\begin{array}{l}\text { Sov. rating } \\
\text { Moodys } \\
2006\end{array}$ & & & 0.0393 & \\
\hline $\begin{array}{l}\text { Sov. rating } \\
\text { S\&P } 2006\end{array}$ & & & & $\begin{array}{l}0.5653 * * * \\
0.0609\end{array}$ \\
\hline Constant & $\begin{array}{l}-1.392 \\
2.188\end{array}$ & $\begin{array}{l}-2.5422 \\
1.9566\end{array}$ & $\begin{array}{l}1.2681 \\
2.3092\end{array}$ & $\begin{array}{l}1.6856 \\
3.1612\end{array}$ \\
\hline Observations & 241 & 180 & 165 & 145 \\
\hline $\begin{array}{l}\text { Adjusted } \\
\text { R-squared }\end{array}$ & 0.7325 & 0.779 & 0.765 & 0.7145 \\
\hline
\end{tabular}

This table presents the effects of bank business models and other variables on bank rating level in 2006. See Sect. 4.1 for further details on these models. Bank Rating CRAs 2006 is the mean of the numeric value of bank rating issued by the three agencies at the end of 2006 (Fitch, Moody's and S\&P). Section 3 explains the scale used to convert ratings into numbers. Traditional Income Ratio, our proxy of bank business models, is equal to: (Net interest income + fees and commissions - dividend income)/Op. income. See Table 1 for the definitions of other variables and Table 2 for summary statistics

$*, * *$ and $* * *$ Indicate statistical significance at the 10,5 and $1 \%$ levels respectively 
estimate the following OLS models:

$$
\begin{aligned}
& \text { b_rat_cra_dif } \mathrm{i}=\alpha+\beta_{1} \text { b_rat_cra } i, 2006+\beta_{2} \text { s_rat_cra } i, 2006+\beta_{3} \text { s_rat_cra_dif } \mathrm{i} \\
& +\beta_{4} \text { trad_inc }_{\mathrm{i}, 2006}+\beta_{5} \text { eq_ta }_{\mathrm{i}, 2006}+\beta_{6} \mathrm{npl}_{\mathrm{i}, 2006}+\beta_{7} \text { cost_inc }_{\mathrm{i}, 2006} \\
& +\beta_{8} \text { roe }_{i, 2006}+\beta_{9} \operatorname{liq}_{\mathrm{i}, 2006}+\beta_{10} \text { size }_{\mathrm{i}, 2006}+\varepsilon_{\mathrm{i}}
\end{aligned}
$$

where for each bank $i, b \_r a t \_c r a$ and $s \_r a t \_c r a$ are as above. In turn, $b \_r a t \_c r a \_d i f$ and $s \_r a t \_c r a \_d i f$ are, respectively, the difference between 2009 and 2006 in the relevant bank's rating and in the sovereign rating for the country in which bank $i$ is headquartered. We run four versions of [2]: one where the ratings - and their changes - are taken as means across the three agencies and an additional one for each of Fitch, Moody's and S\&P's.

For the specification on mean ratings the level of traditional income in 2006 now has a positive and significant impact on bank rating performance, while the main CAMEL financial ratios turn out insignificant (Table 4, column 1). ${ }^{12}$ Moreover, we find that the level of sovereign ratings in 2006 has a negative impact on bank rating performance between 2006 and 2009; whereas positive sovereign ratings changes have, as expected, a positive effect on bank rating performance. To judge the economic significance of these results, we calculate that a one standard deviation increase in the traditional income ratio boosts bank rating performance by 0.55 points, while a one standard deviation increase in 2006 sovereign rating levels depresses bank rating performance by 0.41 points and a one standard deviation increase in sovereign ratings change enhances bank ratings change by 0.44 points. Thus, there is initial evidence that on average, after the outbreak of the crisis, rating agencies started appreciating banks with a traditional business model.

The estimates for each of the three agencies are qualitatively consistent with those for mean ratings. Regarding the appreciation for traditional banking, the coefficients estimated across the three agencies are comparable. However, Fitch assigns a larger value (with an estimated coefficient of 0.0450; Table 4, column 2), then comes Moody's (0.0381, column 3), and S\&P's is the last (0.0295, column 4). Other noteworthy results are the positive impact of the liquidity variable on bank rating changes enacted by Moody's, while S\&P's seems to penalize higher cost-income ratios and granting better rating performance to the banks having relatively higher ratings at the end of 2006.

\footnotetext{
12 An anonymous referee made the well taken point that our traditional income proxy could, in reality, capture other effects favoring the traditional banks not necessarily related to the perception of their business model by the rating agencies. Specifically, the referee argued that our results would be spurious if traditional banks were hit by the crisis less severely than the other banks. In that case, the significance of trad_inc in our regression could, in fact, reflect effects that had little to do with the business model. Thus, we checked whether performance deterioration through the crisis was less intense for traditional banks. Focusing on NPLs and Roe, we found that the deterioration was, if anything, slightly more intense for traditional banks. For them NPLs rose from 2.6 to $3.9 \%$ between 2006 and 2009, while increasing from 2.8 to $3.8 \%$ for the other banks. As to Roe, it dropped from 9.8 to $1.6 \%$ for traditional banks. Even though it decreased in relative terms slightly more for the other banks (from 17.2 to $2.5 \%$ ), these banks still had through the crisis absolute levels of Roe higher than traditional banks. Therefore, in our database, it is not true that traditional banks were hit by the crisis less severely than non-traditional banks.
} 
Table 4 Effects of bank business models on bank rating: OLS estimates on changes in bank ratings between 2006 and 2009

\begin{tabular}{|c|c|c|c|c|}
\hline & $\begin{array}{l}\text { Model 2.a b/se } \\
\text { Bank rating CRAs } \\
\text { Dif. 09-06 }\end{array}$ & $\begin{array}{l}\text { Model 2.b b/se } \\
\text { Bank rating Fitch } \\
\text { Dif. 09-06 }\end{array}$ & $\begin{array}{l}\text { Model 2.c b/se } \\
\text { Bank rating Moody's } \\
\text { Dif. 09-06 }\end{array}$ & $\begin{array}{l}\text { Model 2.d b/se } \\
\text { Bank rating S\&P } \\
\text { Dif. 09-06 }\end{array}$ \\
\hline $\begin{array}{l}\text { Bank rating } \\
\text { CRAs } 2006\end{array}$ & $\begin{array}{l}0.0682 \\
0.0834\end{array}$ & & & \\
\hline $\begin{array}{l}\text { Sov. rating } \\
\text { CRAs } 2006\end{array}$ & $\begin{array}{l}-0.1024^{*} \\
0.0599\end{array}$ & & & \\
\hline $\begin{array}{l}\text { Sov. rating } \\
\text { CRAs Dif. } \\
09-06\end{array}$ & 0.1483 & & & \\
\hline $\begin{array}{l}\text { Traditional } \\
\text { income ratio } \\
2006\end{array}$ & 0.0129 & 0.0221 & 0.0144 & 0.0161 \\
\hline $\begin{array}{l}\text { Equity/tot. } \\
\text { assets } 2006\end{array}$ & $\begin{array}{l}-0.0261 \\
0.0326\end{array}$ & $\begin{array}{l}0.0156 \\
0.0525\end{array}$ & $\begin{array}{l}-0.0158 \\
0.0513\end{array}$ & $\begin{array}{l}-0.031 \\
0.0276\end{array}$ \\
\hline NPL 2006 & $\begin{array}{l}0.0116 \\
0.0279\end{array}$ & $\begin{array}{l}0.0003 \\
0.0341\end{array}$ & $\begin{array}{l}0.0693 \\
0.0463\end{array}$ & $\begin{array}{l}-0.009 \\
0.0365\end{array}$ \\
\hline $\begin{array}{l}\text { Cost-income } \\
2006\end{array}$ & $\begin{array}{l}-0.0217 \\
0.0166\end{array}$ & $\begin{array}{l}-0.0152 \\
0.029\end{array}$ & $\begin{array}{l}-0.0284 \\
0.0177\end{array}$ & $\begin{array}{l}-0.0197 * \\
0.0114\end{array}$ \\
\hline Roe 2006 & $\begin{array}{l}0.0145 \\
0.0158\end{array}$ & $\begin{array}{l}0.0203 \\
0.0244\end{array}$ & $\begin{array}{l}0.0107 \\
0.0185\end{array}$ & $\begin{array}{l}0.0169 \\
0.0159\end{array}$ \\
\hline Liquidity 2006 & $\begin{array}{l}0.0084 \\
0.0067\end{array}$ & $\begin{array}{l}0.0105 \\
0.0105\end{array}$ & $\begin{array}{l}0.0226^{* *} \\
0.0093\end{array}$ & $\begin{array}{l}-0.0005 \\
0.0066\end{array}$ \\
\hline Size 2006 & $\begin{array}{l}-0.1838^{* *} \\
0.0817\end{array}$ & $\begin{array}{l}-0.1572 \\
0.0987\end{array}$ & $\begin{array}{l}-0.2443 \\
0.1531\end{array}$ & $\begin{array}{l}-0.1465 \\
0.093\end{array}$ \\
\hline $\begin{array}{l}\text { Bank rating } \\
\text { Fitch } 2006\end{array}$ & & $\begin{array}{l}0.085 \\
0.1119\end{array}$ & & \\
\hline $\begin{array}{l}\text { Sov. rating } \\
\text { Fitch } 2006\end{array}$ & & $\begin{array}{l}-0.1378 * * \\
0.0617\end{array}$ & & \\
\hline $\begin{array}{l}\text { Sov. rating } \\
\text { Fitch Dif. } \\
09-06\end{array}$ & & 0.1801 & & \\
\hline
\end{tabular}


Table 4 continued

\begin{tabular}{|c|c|c|c|c|}
\hline & $\begin{array}{l}\text { Model 2.a b/se } \\
\text { Bank rating CRAs } \\
\text { Dif. 09-06 }\end{array}$ & $\begin{array}{l}\text { Model } 2 . \mathrm{b} \text { b/se } \\
\text { Bank rating Fitch } \\
\text { Dif. 09-06 }\end{array}$ & $\begin{array}{l}\text { Model 2.c b/se } \\
\text { Bank rating Moody's } \\
\text { Dif. 09-06 }\end{array}$ & $\begin{array}{l}\text { Model } 2 . \mathrm{d} \mathrm{b} / \mathrm{se} \\
\text { Bank rating S\&P } \\
\text { Dif. 09-06 }\end{array}$ \\
\hline $\begin{array}{l}\text { Bank rating } \\
\text { Moodys } \\
2006\end{array}$ & & & $\begin{array}{l}-0.171 \\
0.1036\end{array}$ & \\
\hline $\begin{array}{l}\text { Sov. rating } \\
\text { Moodys } \\
2006\end{array}$ & & & 0.0839 & \\
\hline $\begin{array}{l}\text { Sov. rating } \\
\text { Moodys Dif. } \\
09-06\end{array}$ & & & $\begin{array}{l}0.1468 \\
0.2188\end{array}$ & \\
\hline $\begin{array}{c}\text { Bank rating } \\
\text { S\&P } 2006\end{array}$ & & & & $\begin{array}{l}0.1309 * \\
0.0766\end{array}$ \\
\hline $\begin{array}{l}\text { Sov. rating } \\
\text { S\&P } 2006\end{array}$ & & & & $\begin{array}{l}-0.2054^{* * *} \\
0.068\end{array}$ \\
\hline $\begin{array}{l}\text { Sov. rating } \\
\text { S\&P Dif. } \\
\text { 09-06 }\end{array}$ & & & & $0.3302^{* *}$ \\
\hline & & & & 0.1378 \\
\hline Constant & $\begin{array}{l}-0.4235 \\
2.1375\end{array}$ & $\begin{array}{l}-1.2145 \\
4.2829\end{array}$ & $\begin{array}{l}0.886 \\
2.4922\end{array}$ & $\begin{array}{l}1.6303 \\
1.8496\end{array}$ \\
\hline Observations & 241 & 178 & 162 & 145 \\
\hline $\begin{array}{l}\text { Adjusted } \\
\text { R-squared }\end{array}$ & 0.1774 & 0.2244 & 0.0931 & 0.1083 \\
\hline
\end{tabular}

This table presents the effects of bank business models and other variables on changes in bank ratings between 2006 and 2009. See Sect. 4.1 for further details on these models. Section 3 explains the scale used to convert ratings into numbers. Traditional income ratio, our proxy of bank business models, is equal to: (Net interest income + fees and commissions - dividend income)/Op. income. See Table 1 for the definitions of other variables and Table 2 for summary statistics

$*, * *$ and $* * *$ Indicate statistical significance at the 10,5 and $1 \%$ levels respectively

\subsection{Panel Models}

To further check the robustness of our findings, we now use panel data estimates. Based on the Hausman test, we select a bank fixed-effect estimator to control for unobserved, time invariant, individual bank-specific characteristics. In order to investigate the changing behavior of rating agencies over time, we use a sample splitting whereby we estimate two separate sub-panels respectively referring to the sample periods 2006-2007 (t1) and 2008-2009 (t2): 


$$
\begin{aligned}
& \text { b_rat_cra } a_{i, t, j}=\alpha_{i}+\beta_{1} s_{-} \text {rat_cra } a_{i, t, j}+\beta_{2} \text { trad_inc }_{i, t, j}+\beta_{3} \text { eq_ta }_{i, t, j} \\
& +\beta_{4} \text { npl }_{i, t, j}+\beta_{5} \text { cost_inc }_{i, t, j}+\beta_{6} \text { roe }_{i, t, j}+\beta_{7} \text { liq }_{i, t, j}+\beta_{8} \text { size }_{i, t, j} \\
& +\mathrm{y}_{-} \mathrm{j}+\varepsilon_{\mathrm{i}, \mathrm{t}, \mathrm{j}}
\end{aligned}
$$

where $j$ refers, alternatively, to $\mathrm{t} 1$ and $\mathrm{t} 2$ and $y_{-} j$ is a time fixed effect dummy for 2006 in $\mathrm{t} 1$ and for 2008 in $\mathrm{t} 2,{ }^{13} \alpha_{i}$ are the bank fixed effects. Again, we estimate four versions of each sub-panel [3]: one where the ratings are taken as means across the three agencies and an additional one for each of Fitch, Moody's and S\&P's.

Starting with the first sub-sample of 2006-2007-i.e., before the US subprime crisis became global and before the crisis actually damaged banks-and referring to the mean rating specification, the traditional income ratio has no impact on bank ratings (see Table 5, column 1) while sovereign ratings and the cost-income ratio are the only two significant regressors. In the second sub-sample (2008-2009), traditional income has a positive and significant impact on bank ratings (Table 6, column 1). In other words, banks with a business model more oriented to traditional activities have a better rating performance after the outbreak of the crisis. Among the CAMEL regressors, we notice that lower NPL banks have better rating performance, while the significantly negative effect of liquidity contrasts our expectations.

The results for the individual agencies are in line with what found for the mean ratings. Specifically, for each agency traditional banking is unrelated to bank ratings in the 2006-2007 sub-panel (Table 5, columns 2, 3, and 4) while it gains a positive and significant impact in the 2008-2009 sub-panel (Table 6, columns 2, 3, and 4). For Fitch the effect of liquidity is in line with our expectations (Table 6, column 2). In the case of Moody's, the level of NPLs has a negative and significant impact on bank rating between 2008 and 2009 (Table 6, column 3). For S\&P's almost all CAMEL variables significantly relate to bank ratings between 2008 and 2009 (Table 6, column 4).

Thus, the panel results confirm the preliminary conclusions based on cross-section models: after the outbreak of the crisis orientation towards a traditional business model becomes a positive factor for the level of bank rating for all three main agencies.

\subsection{Robustness Checks}

\subsubsection{Cross-Section Models}

Endogeneity might be a problem for our base models. The main reason is that the sovereign debt assessment takes into consideration the risks in the banking sector of the country (e.g., Moody's Investor Service 2012). To check for this possible issue, following Estrella and Schich (2012) we substitute the country debt to GDP ratio for the sovereign rating in models 1.a and 2.a. As shown in Table 7 (columns 1 and 2, models 4.1. and 4.2 for models 1 .a and 2.a respectively) the role of the traditional income ratio is unchanged. Banks in countries with higher public debt to GDP ratios

\footnotetext{
13 We use also time fixed effects as the F-test of the null that the coefficients of the year dummies are equal to zero is strongly rejected.
} 
Table 5 Effects of bank business models on bank rating: panel fixed effects estimates—sample 2006-2007

\begin{tabular}{|c|c|c|c|c|}
\hline & $\begin{array}{l}\text { Model 3.1a b/se } \\
\text { Bank rating CRAs } \\
\text { 2006-2007 }\end{array}$ & $\begin{array}{l}\text { Model } 3.1 \mathrm{~b} \text { b/se } \\
\text { Bank rating Fitch } \\
\text { 2006-2007 }\end{array}$ & $\begin{array}{l}\text { Model 3.1c b/se } \\
\text { Bank rating } \\
\text { Moody's 2006-2007 }\end{array}$ & $\begin{array}{l}\text { Model 3.1d b/se } \\
\text { Bank rating S\&P } \\
\text { 2006-2007 }\end{array}$ \\
\hline $\begin{array}{l}\text { Sov. rating } \\
\text { CRAs }\end{array}$ & $\begin{array}{l}-0.2366^{*} \\
0.1266\end{array}$ & & & \\
\hline $\begin{array}{l}\text { Traditional } \\
\text { income ratio }\end{array}$ & $\begin{array}{l}0.0104 \\
0.01\end{array}$ & $\begin{array}{l}0.0144 \\
0.0124\end{array}$ & 0.0095 & $\begin{array}{l}-0.0023 \\
0.0063\end{array}$ \\
\hline $\begin{array}{l}\text { Equity/tot. } \\
\text { assets }\end{array}$ & $\begin{array}{l}-0.0139 \\
0.0437\end{array}$ & $\begin{array}{l}0.0277 \\
0.0574\end{array}$ & $\begin{array}{l}-0.0496 \\
0.083\end{array}$ & $\begin{array}{l}-0.007 \\
0.0322\end{array}$ \\
\hline NPL & $\begin{array}{l}-0.0022 \\
0.0232\end{array}$ & $\begin{array}{l}0.0184 \\
0.023\end{array}$ & $\begin{array}{l}-0.0222 \\
0.034\end{array}$ & $\begin{array}{l}0.0223 \\
0.0294\end{array}$ \\
\hline Cost-income & $\begin{array}{l}-0.0236^{*} \\
0.0138\end{array}$ & $\begin{array}{l}-0.0203 \\
0.017\end{array}$ & $\begin{array}{l}-0.0041 \\
0.0127\end{array}$ & $\begin{array}{l}-0.0297 * * * \\
0.0066\end{array}$ \\
\hline Roe & $\begin{array}{l}0.0132 \\
0.0111\end{array}$ & $\begin{array}{l}0.0207 * * \\
0.0103\end{array}$ & $\begin{array}{l}-0.0033 \\
0.0097\end{array}$ & $\begin{array}{l}-0.0124 * \\
0.0073\end{array}$ \\
\hline Liquidity & $\begin{array}{l}0.0004 \\
0.0055\end{array}$ & $\begin{array}{l}0.0033 \\
0.0042\end{array}$ & $\begin{array}{l}0.0239 * * \\
0.0096\end{array}$ & $\begin{array}{l}-0.0016 \\
0.0036\end{array}$ \\
\hline $\begin{array}{l}\text { Sov. rating } \\
\text { Fitch }\end{array}$ & & $\begin{array}{l}0.1005 \\
0.1664\end{array}$ & & \\
\hline $\begin{array}{l}\text { Sov. rating } \\
\text { Moodys }\end{array}$ & & & $\begin{array}{l}-0.1079 * * \\
0.0441\end{array}$ & \\
\hline $\begin{array}{l}\text { Sov. rating } \\
\text { S\&P }\end{array}$ & & & & $\begin{array}{l}0.3372 * * * \\
0.1016\end{array}$ \\
\hline Constant & $\begin{array}{l}19.3442 * * * \\
2.3579\end{array}$ & $\begin{array}{l}12.0279 * * * \\
2.7566\end{array}$ & $\begin{array}{l}17.7512 * * * \\
1.2312\end{array}$ & $\begin{array}{l}10.7820 * * * \\
2.0839\end{array}$ \\
\hline Observations & 482 & 359 & 339 & 290 \\
\hline $\begin{array}{l}\text { Bank fixed } \\
\text { effects }\end{array}$ & Yes & Yes & Yes & Yes \\
\hline $\begin{array}{l}\text { Adjusted } \\
\text { R-squared }\end{array}$ & 0.3336 & 0.2369 & 0.5226 & 0.3408 \\
\hline
\end{tabular}

This table presents the effects of bank business models and other variables on bank rating level in 2006 and 2007 using panel fixed effects estimator. Bank Rating CRAs is the mean of the numeric value of bank rating issued by the 3 agencies (Fitch, Moody's and S\&P). See Sect. 4.2 for further details on these models. Section 3 explains the scale used to convert ratings into numbers. Traditional Income Ratio, our proxy of bank business models, is equal to: (Net interest income + fees and commissions - dividend income)/Op. income. See Table 1 for the definitions of other variables and Table 2 for summary statistics $*, * *$ and $* * *$ Indicate statistical significance at the 10,5 and $1 \%$ levels respectively 
Table 6 Effects of bank business models on bank rating: panel fixed effects estimates—sample 2008-2009

\begin{tabular}{|c|c|c|c|c|}
\hline & $\begin{array}{l}\text { Model } 3.2 \mathrm{a} \text { b/se } \\
\text { Bank rating CRAs } \\
\text { 2008-2009 }\end{array}$ & $\begin{array}{l}\text { Model } 3.2 \mathrm{~b} \text { b/se } \\
\text { Bank rating Fitch } \\
\text { 2008-2009 }\end{array}$ & $\begin{array}{l}\text { Model 3.2c b/se } \\
\text { Bank rating } \\
\text { Moody's 2008-2009 }\end{array}$ & $\begin{array}{l}\text { Model } 3.2 \mathrm{~d} \text { b/se } \\
\text { Bank rating S\&P } \\
\text { 2008-2009 }\end{array}$ \\
\hline $\begin{array}{l}\text { Sov. rating } \\
\text { CRAs }\end{array}$ & $\begin{array}{l}0.5449 * * * \\
0.1864\end{array}$ & & & \\
\hline \multirow[t]{2}{*}{$\begin{array}{l}\text { Traditional } \\
\text { income ratio }\end{array}$} & $0.0151 * * *$ & $0.0270 * * *$ & $0.0102 *$ & $0.0228 * *$ \\
\hline & 0.0049 & 0.0097 & 0.0057 & 0.0092 \\
\hline \multirow[t]{2}{*}{$\begin{array}{l}\text { Equity/tot. } \\
\text { assets }\end{array}$} & -0.1133 & 0.1152 & 0.0149 & -0.1402 \\
\hline & 0.1092 & 0.105 & 0.104 & 0.1067 \\
\hline \multirow[t]{2}{*}{ NPL } & $-0.1927 * * *$ & -0.0794 & $-0.2999 * * *$ & $-0.2574 * * *$ \\
\hline & 0.0539 & 0.0624 & 0.0911 & 0.0834 \\
\hline \multirow[t]{2}{*}{ Cost-income } & $-0.0224 * *$ & -0.0173 & -0.0134 & $-0.0416^{* * *} *$ \\
\hline & 0.0099 & 0.011 & 0.009 & 0.0103 \\
\hline \multirow[t]{2}{*}{ Roe } & -0.0261 & 0.001 & -0.029 & $-0.0540^{* * *}$ \\
\hline & 0.0172 & 0.0151 & 0.0212 & 0.0171 \\
\hline \multirow[t]{2}{*}{ Liquidity } & $-0.0395^{*}$ & $0.0280 *$ & -0.0058 & $-0.0377 * *$ \\
\hline & 0.0234 & 0.0168 & 0.0117 & 0.0158 \\
\hline $\begin{array}{l}\text { Sov. rating } \\
\text { Fitch }\end{array}$ & & $\begin{array}{l}0.5411 * * * \\
0.1532\end{array}$ & & \\
\hline $\begin{array}{l}\text { Sov. rating } \\
\text { Moodys }\end{array}$ & & & $\begin{array}{l}0.6955^{* * * *} \\
0.1878\end{array}$ & \\
\hline $\begin{array}{l}\text { Sov. rating } \\
\text { S\&P }\end{array}$ & & & & $\begin{array}{l}0.2642 \\
0.1708\end{array}$ \\
\hline \multirow[t]{2}{*}{ Constant } & $6.8146^{* *}$ & 1.7677 & 3.4759 & $12.0975 * * *$ \\
\hline & 2.9437 & 3.3702 & 3.734 & 3.5357 \\
\hline Observations & 482 & 358 & 346 & 290 \\
\hline $\begin{array}{l}\text { Bank fixed } \\
\text { effects }\end{array}$ & Yes & Yes & Yes & Yes \\
\hline $\begin{array}{l}\text { Adjusted } \\
\text { R-squared }\end{array}$ & 0.3981 & 0.3595 & 0.3497 & 0.5696 \\
\hline
\end{tabular}

This table presents the effects of bank business models and other variables on bank rating level in 2008 and 2009 using panel fixed effects estimator. Bank Rating CRAs is the mean of the numeric value of bank rating issued by the 3 agencies (Fitch, Moody's and S\&P). See Sect. 4.2 for further details on these models. Section 3 explains the scale used to convert ratings into numbers. Traditional income ratio, our proxy of bank business models, is equal to: (Net interest income + fees and commissions - dividend income)/Op. income. See Table 1 for the definitions of other variables and Table 2 for summary statistics $*, * *$ and $* * *$ Indicate statistical significance at the 10,5 and $1 \%$ levels respectively 


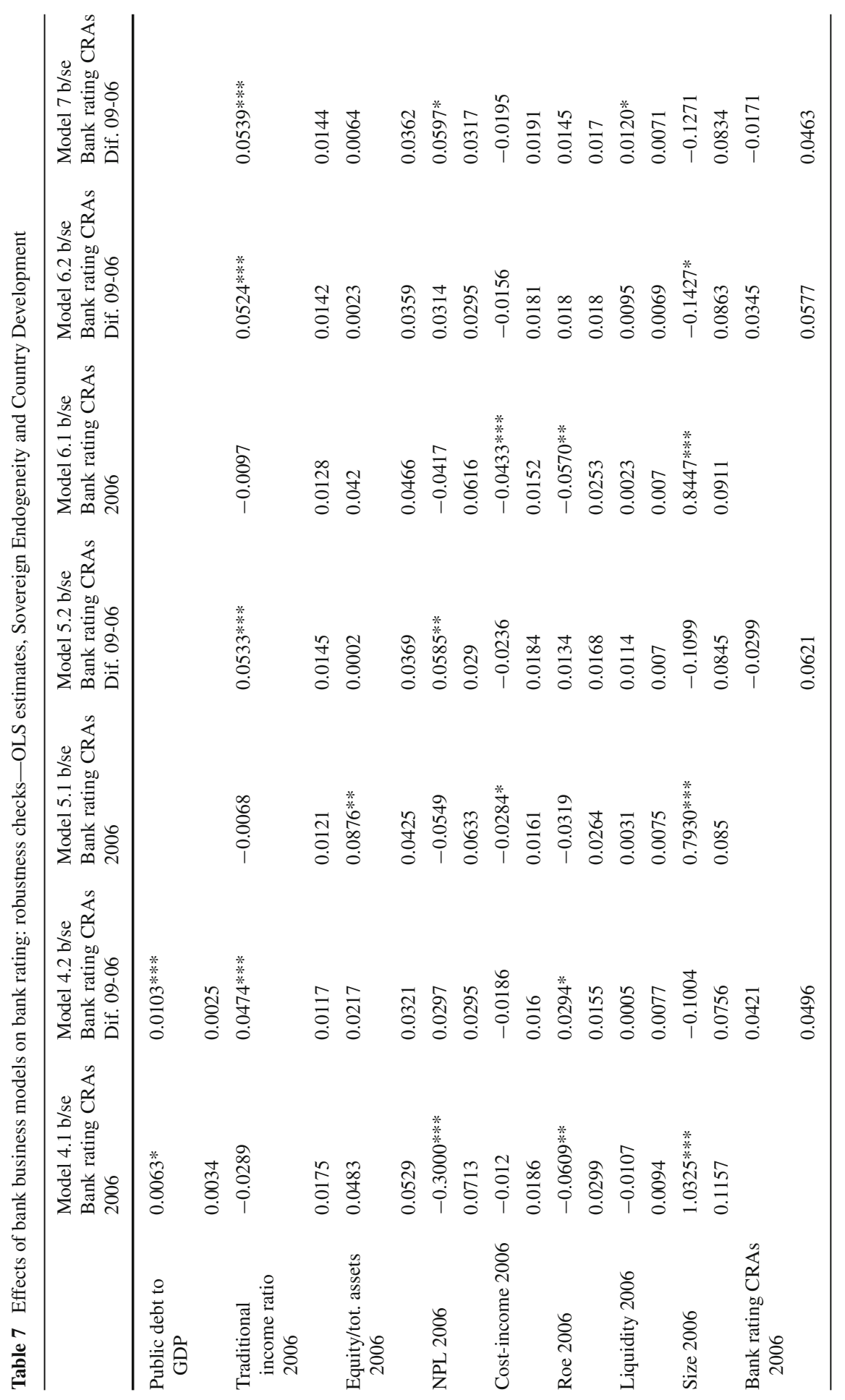




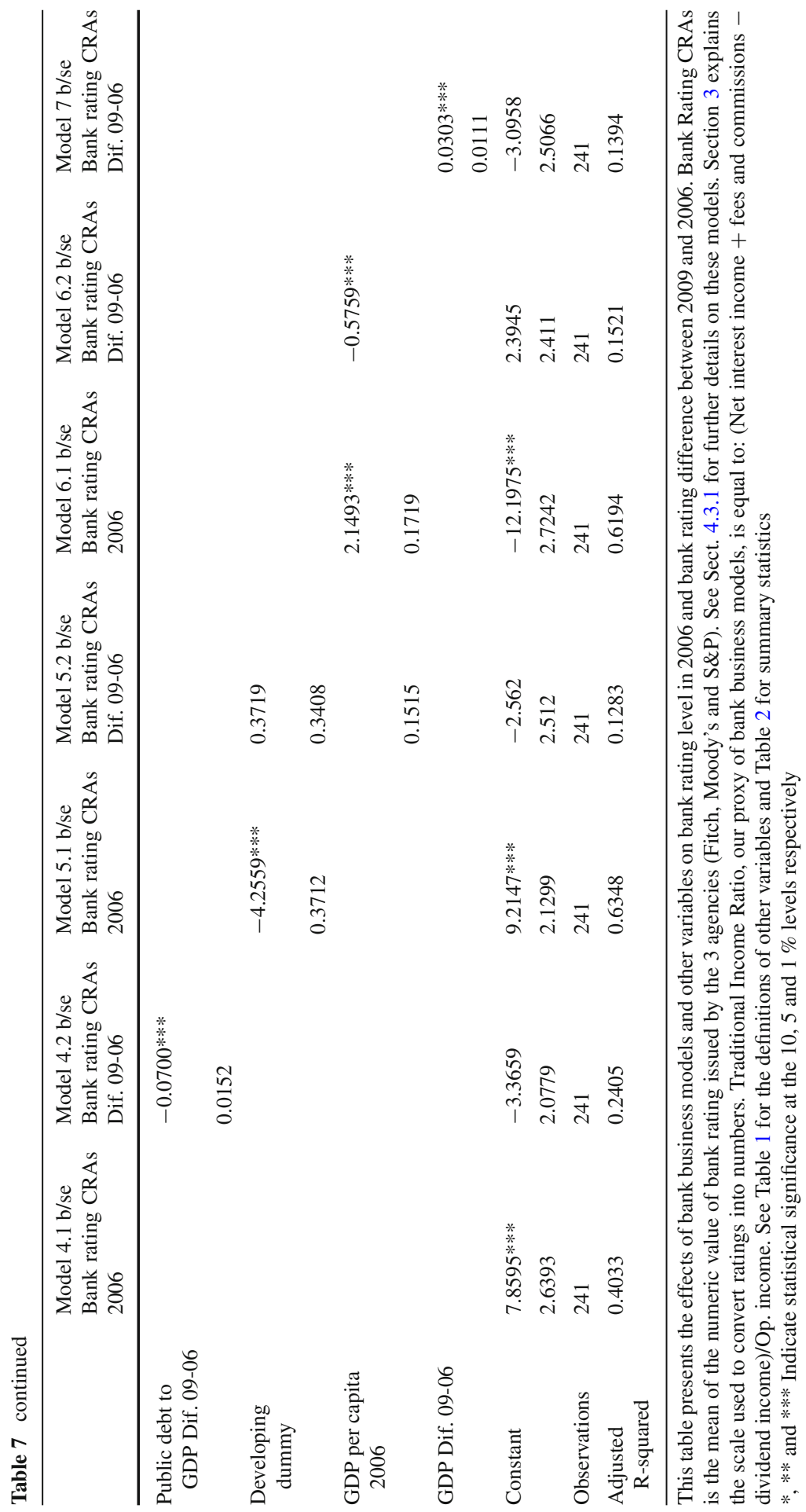


had better ratings in 2006 due to the fact that in our sample ratios were higher for developed countries (79.5\%) vis-à-vis developing countries (44.4\%). As expected, banks in countries with higher increase of the public debt to GDP ratio between 2006 and 2009 had worse rating performance.

Another issue is the degree of economic development as our sample includes developed as well as developing countries. Bank and country specific factors might have different weights in the two groups of countries in the models used by the rating agencies (Ferri and Liu 2003; Ferri 2004; Caporale et al. 2011, 2012). We check this through a dummy equal to one for countries classified as developing by the IMF. As shown in Table 7 (models 5.1 and 5.2 respectively), the role of the traditional business model is unchanged. Moreover, the dummy confirms that 2006 bank ratings were systematically lower in developing countries (model 5.1). On the contrary, the negative impact of the log of per-capita GDP on rating changes (model 6.2) suggests that post-crisis rating performance was worse for rich countries' banks. This is not surprising given that the crisis emanated from the U.S. and hit the rich countries more severely. Finally, the role of traditional banking is unaffected also controlling for the country-level severity of the crisis, as proxied by the GDP variation between 2006 and 2009 (Table 7, last column).

For additional robustness checks, we use different CAMEL financial ratios, one for each area, in model 1 (see Table 1 for data sources and definitions and Table 2 for summary statistics). Specifically, tangible common equity/tangible assets replaces equity/total assets (Table 8, column 1), loan impairment charges/average gross loan instead of NPL (column 2), cost/gross revenues in lieu of cost/income (column 3), return on assets in lieu of return on equity (column 4), liquid assets/total deposits and borrowings instead of liquid assets/customers and short-term funding (column 5). The results do not change: in 2006 the traditional income ratio has no impact on bank ratings.

Analogously, the alternative CAMEL financial ratios do not alter the results of model [2]: the traditional income ratio has a positive impact on 2006-2009 bank rating changes (Table 9).

To deal with possibly not normally distributed errors, we run quantile regressions of models [1] and [2] that avoid assumptions about the parametric distribution of regression errors and are more robust than OLS to outliers (Cameron and Trivedi 2009). The results are unaffected (Table 10, columns 1 and 2).

Finally, we check for specific characteristics of each country that may influence bank rating performance using a random-intercept model. This model, also called "mixed-effects model", contains both fixed and random effects. The fixed effects are analogous to the standard regression coefficients and are estimated directly, while the random ones are not directly estimated but are summarized according to their estimated variances. Specifically, random effects may take the form of random intercepts. In a cross-section model, random effects are useful for modeling intra-group correlation; that is, observations in the same panel are correlated because they share common panel-level random effects. Though country specific characteristics are significant, base models results don't change (Table 10, columns 3 and 4). 


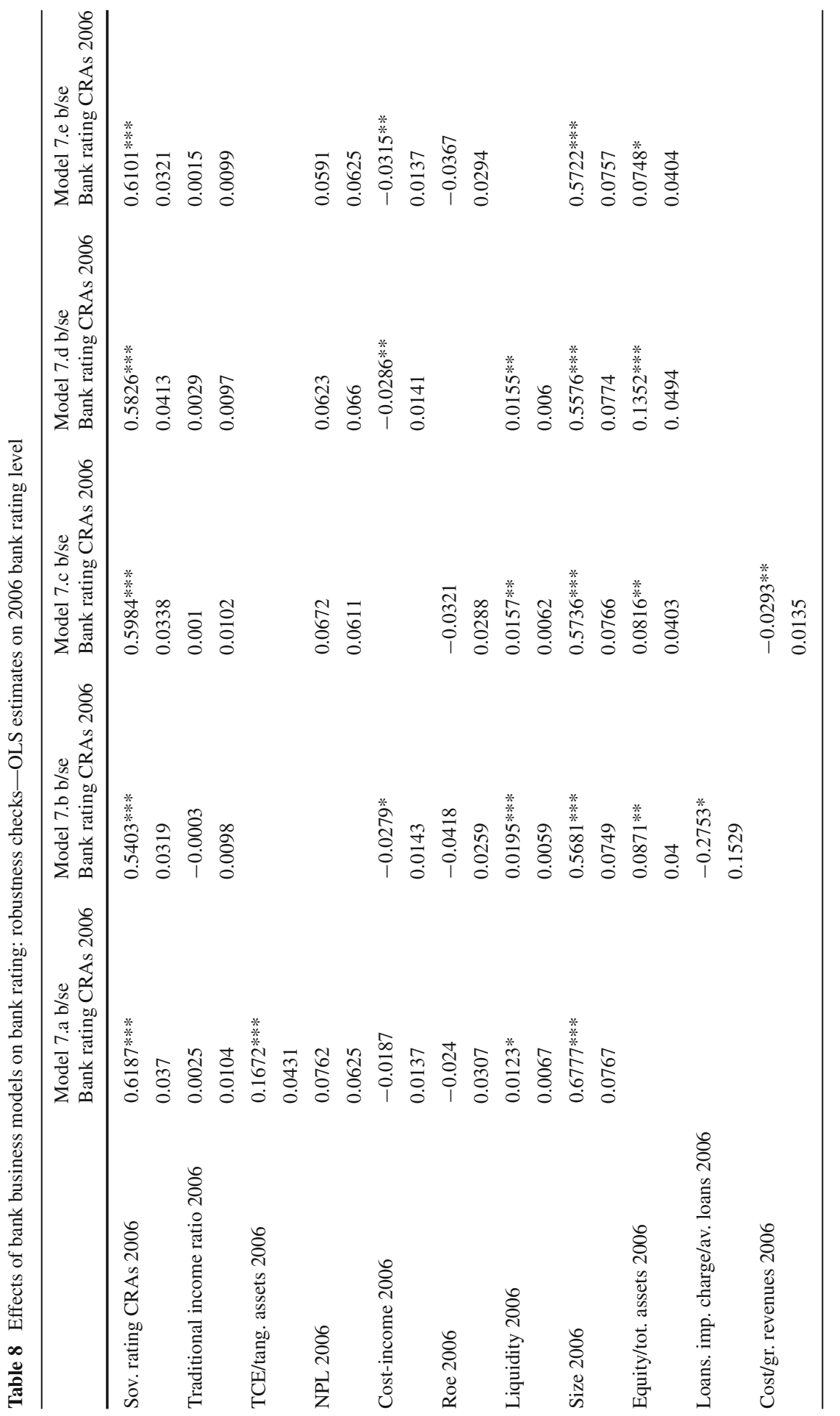




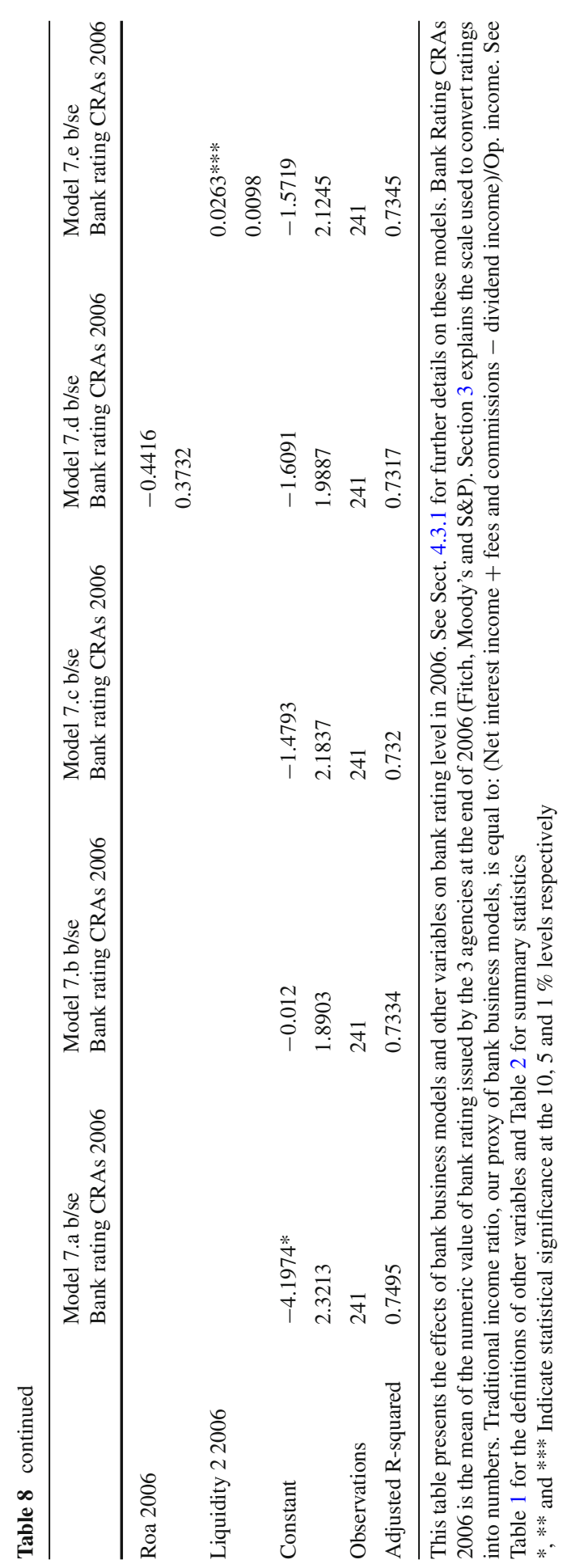


Table 9 Effects of bank business models on bank rating: robustness checks-OLS estimates, bank rating difference 2009-2006

\begin{tabular}{|c|c|c|c|c|c|}
\hline & $\begin{array}{l}\text { Model 8.a b/se } \\
\text { Bank rating } \\
\text { CRAs Dif 09-06 }\end{array}$ & $\begin{array}{l}\text { Model 8.b use } \\
\text { Bank rating } \\
\text { CRAs Dif 09-06 }\end{array}$ & $\begin{array}{l}\text { Model 8.c use } \\
\text { Bank rating } \\
\text { CRAs Dif 09-06 }\end{array}$ & $\begin{array}{l}\text { Model 8.d b/se } \\
\text { Bank rating } \\
\text { CRAs Dif 09-06 }\end{array}$ & $\begin{array}{l}\text { Model 8.e b/se } \\
\text { Bank rating } \\
\text { CRAs Dif 09-06 }\end{array}$ \\
\hline \multirow{2}{*}{$\begin{array}{l}\text { Bank rating } \\
\text { CRAs } 2006\end{array}$} & 0.0426 & 0.0687 & 0.0693 & 0.0569 & 0.0514 \\
\hline & 0.0856 & 0.0842 & 0.0837 & 0.0835 & 0.0815 \\
\hline \multirow{2}{*}{$\begin{array}{l}\text { Sov. rating } \\
\text { CRAs } 2006\end{array}$} & -0.0828 & $-0.1117 * *$ & $-0.1028^{*}$ & -0.1036 & -0.0728 \\
\hline & 0.0635 & 0.0565 & 0.06 & 0.064 & 0.0558 \\
\hline \multirow{2}{*}{$\begin{array}{l}\text { Sov. rating } \\
\text { CRAs Dif. } \\
09-06\end{array}$} & $0.5670 * * *$ & $0.6229 * * *$ & $0.6074 * * *$ & $0.6075 * * *$ & $0.5995 * * *$ \\
\hline & 0.1427 & 0.1529 & 0.1487 & 0.1532 & 0.149 \\
\hline \multirow{2}{*}{$\begin{array}{l}\text { Traditional } \\
\text { income ratio } \\
2006\end{array}$} & $0.0497 * * *$ & $0.0464 * * *$ & $0.0468 * * *$ & $0.0437 * * *$ & $0.0510^{* * *}$ \\
\hline & 0.0123 & 0.0129 & 0.0129 & 0.0122 & 0.0151 \\
\hline \multirow{2}{*}{$\begin{array}{l}\text { TCE/tang. } \\
\text { assets } 2006\end{array}$} & 0.0276 & & & & \\
\hline & 0.0347 & & & & \\
\hline \multirow[t]{2}{*}{ NPL 2006} & 0.0189 & & 0.0117 & 0.0006 & 0.0014 \\
\hline & 0.0277 & & 0.0279 & 0.03 & 0.0289 \\
\hline \multirow{2}{*}{$\begin{array}{l}\text { Cost-income } \\
2006\end{array}$} & -0.017 & -0.0214 & & -0.0278 & -0.0257 \\
\hline & 0.0168 & 0.0167 & & 0.0181 & 0.0165 \\
\hline \multirow[t]{2}{*}{ Roe 2006} & 0.0184 & 0.0131 & 0.015 & & 0.0074 \\
\hline & 0.0148 & 0.0149 & 0.0158 & & 0.0158 \\
\hline \multirow{2}{*}{$\begin{array}{l}\text { Liquidity } \\
2006\end{array}$} & 0.008 & 0.009 & 0.0084 & 0.0103 & \\
\hline & 0.0069 & 0.0069 & 0.0067 & 0.0067 & \\
\hline \multirow[t]{2}{*}{ Size 2006} & -0.107 & $-0.1858 * *$ & $-0.1834 * *$ & $-0.1792 * *$ & $-0.2049 * *$ \\
\hline & 0.0892 & 0.0812 & 0.0818 & 0.083 & 0.088 \\
\hline \multirow{2}{*}{$\begin{array}{l}\text { Equity/tot. } \\
\text { assets } 2006\end{array}$} & & -0.0256 & -0.0259 & -0.0256 & -0.0318 \\
\hline & & 0.0327 & 0.0327 & 0.0285 & 0.0334 \\
\hline \multirow{2}{*}{$\begin{array}{l}\text { Loans. imp. } \\
\text { charge/av. } \\
\text { loans } 2006\end{array}$} & & -0.0448 & & & \\
\hline & & 0.1062 & & & \\
\hline \multirow{2}{*}{$\begin{array}{l}\text { Cost/gr. } \\
\text { revenues } \\
2006\end{array}$} & & & -0.0211 & & \\
\hline & & & 0.0166 & & \\
\hline
\end{tabular}


Table 9 continued

\begin{tabular}{clllll}
\hline & $\begin{array}{l}\text { Model 8.a b/se } \\
\text { Bank rating } \\
\text { CRAs Dif 09-06 }\end{array}$ & $\begin{array}{l}\text { Model 8.b use } \\
\text { Bank rating } \\
\text { CRAs Dif 09-06 }\end{array}$ & $\begin{array}{l}\text { Model 8.c use } \\
\text { Bank rating } \\
\text { CRAs Dif 09-06 }\end{array}$ & $\begin{array}{l}\text { Model 8.d b/se } \\
\text { Bank rating } \\
\text { CRAs Dif 09-06 }\end{array}$ & $\begin{array}{l}\text { Model 8.e b/se } \\
\text { Bank rating } \\
\text { CRAs Dif 09-06 }\end{array}$ \\
\hline Roa 2006 & & & & -0.0553 & \\
& & & & 0.2335 & \\
Liquidity2 & & & & $0.0258^{* * *}$ \\
2006 & & & & & 0.0126 \\
& & -0.1762 & -0.4767 & 0.5679 & -0.7269 \\
Constant & -2.1802 & 2.0471 & 2.14 & 2.2236 & 2.1492 \\
& 2.0983 & 241 & 241 & 241 & 241 \\
Observations & 241 & 0.1774 & 0.1769 & 0.1748 & 0.1921 \\
Adjusted & 0.1771 & & & & \\
R-squared & & & & & \\
\hline
\end{tabular}

This table presents the effects of bank business models and other variables on bank rating difference between 2009 and 2006. See Sect. 4.3.1 for further details on these models. Bank Rating CRAs 2006 is the mean of the numeric value of bank rating issued by the three agencies at the end of 2006 (Fitch, Moody's and S\&P). Section 3 explains the scale used to convert ratings into numbers. Traditional Income Ratio, our proxy of bank business models, is equal to: (Net interest income + fees and commissions - dividend income)/Op. income. See Table 1 for the definitions of other variables and Table 2 for summary statistics $*, * *$ and $* * *$ Indicate statistical significance at the 10,5 and $1 \%$ levels respectively

\subsubsection{Panel Models}

We control also panel specifications for sovereign endogeneity and country development (Table 11, columns 1 and 2). The role of the traditional business model is unchanged. The public debt to GDP ratio is negative and significant only in the second sub-period when, with the crisis, the fast and steep increase of the ratio raised worries on the sustainability of public finance in various countries. The developing countries dummy is negative and significant in both sub-periods, meaning that bank ratings are lower in these countries (columns 3 and 4). ${ }^{14}$ This result is confirmed also proxying economic development by GDP per-capita (columns 5 and 6). Finally, GDP growth, a proxy for the severity of the crisis, is not significant (columns 7 and 8).

Estimating the panel models of Sect. 4.2 using the different CAMEL financial ratios as in Sect. 4.3.1 does not change the results: the relationship between traditional income and bank ratings becomes significant after the outbreak of the crisis (Table 12).

An alternative way to highlight the role of traditional income is to use fixed effects estimator on the full sample with two new variables: trad_inc_0607 and trad_inc_0809. The former (latter) has the value of traditional income ratio in 2006 and 2007 (2008 and 2009) and zero in 2008 and 2009 (2006 and 2007). The traditional income ratio does not influence the level of bank ratings in 2006 and 2007

14 These two models are estimated with random effect to allow the use of the developing countries dummy. 
Table 10 Effects of bank business models on bank rating: robustness checks-quantile regression and random model

\begin{tabular}{|c|c|c|c|c|}
\hline & $\begin{array}{l}\text { Model } 9.1 \mathrm{~b} / \mathrm{se} \\
\text { Model: quantile } \\
\text { regression } \\
\text { Bank rating } \\
\text { CRAs } 2006\end{array}$ & $\begin{array}{l}\text { Model } 9.2 \text { b/se } \\
\text { Model: quantile } \\
\text { regression } \\
\text { Bank rating CRAs } \\
\text { Dif. 06-09 }\end{array}$ & $\begin{array}{l}\text { Model } 10.1 \mathrm{~b} / \mathrm{se} \\
\text { Model: random } \\
\text { intercept } \\
\text { Bank rating CRAs } \\
2006\end{array}$ & $\begin{array}{l}\text { Model } 10.2 \mathrm{~b} / \mathrm{se} \\
\text { Model: random } \\
\text { intercept } \\
\text { Bank rating CRAs } \\
\text { Dif. 06-09 }\end{array}$ \\
\hline \multirow[t]{2}{*}{ Sov. rating CRAs } & $0.6176 * * *$ & $-0.0678 *$ & $0.5979 * * *$ & 0.0226 \\
\hline & 0.0451 & 0.037 & 0.0465 & 0.0629 \\
\hline \multirow{2}{*}{$\begin{array}{l}\text { Traditional income } \\
\text { ratio }\end{array}$} & 0.0074 & $0.0202 * * *$ & 0.0128 & $0.0460 * * *$ \\
\hline & 0.0136 & 0.0075 & 0.0092 & 0.0111 \\
\hline \multirow[t]{2}{*}{ Equity/tot. assets } & $0.0846^{* *}$ & -0.006 & $0.0936^{* * *}$ & 0.0248 \\
\hline & 0.0412 & 0.0232 & 0.0291 & 0.0353 \\
\hline \multirow[t]{2}{*}{ NPL } & $0.0942 *$ & -0.0378 & 0.0089 & 0.0036 \\
\hline & 0.0519 & 0.0289 & 0.0388 & 0.0448 \\
\hline \multirow[t]{2}{*}{ Cost-income } & $-0.0338^{* *}$ & -0.0019 & -0.016 & -0.0086 \\
\hline & 0.0143 & 0.008 & 0.0099 & 0.0118 \\
\hline \multirow[t]{2}{*}{ Roe } & 0.001 & -0.0043 & -0.0203 & $0.0382 * *$ \\
\hline & 0.0192 & 0.0106 & 0.013 & 0.0156 \\
\hline \multirow[t]{2}{*}{ Liquidity } & $0.0187 * *$ & 0.002 & 0.0027 & 0.0008 \\
\hline & 0.0091 & 0.005 & 0.0069 & 0.0078 \\
\hline \multirow[t]{2}{*}{ Size } & $0.5317 * * *$ & -0.0838 & $0.6444 * * *$ & -0.1232 \\
\hline & 0.1101 & 0.0669 & 0.0732 & 0.0992 \\
\hline \multirow[t]{2}{*}{ Bank rating CRAs } & & 0.0115 & & -0.0639 \\
\hline & & 0.0468 & & 0.0747 \\
\hline \multirow{2}{*}{$\begin{array}{l}\text { Sov. rating CRAs Dif. } \\
\text { 06-09 }\end{array}$} & & $0.5900^{* * * *}$ & & $0.6812 * * *$ \\
\hline & & 0.1118 & & 0.2025 \\
\hline \multirow[t]{2}{*}{ Constant } & -2.4216 & 0.4843 & $-3.4439 * *$ & -2.4582 \\
\hline & 2.3639 & 1.3042 & 1.735 & 1.9828 \\
\hline \multicolumn{5}{|l|}{ Random-effects } \\
\hline \multirow[t]{2}{*}{ std. dev. $\sigma u$} & & & $0.9467 * * *$ & $0.5996^{* * * *}$ \\
\hline & & & 0.1548 & 0.1235 \\
\hline \multicolumn{2}{|c|}{$\begin{array}{l}\text { LR test vs. base } \\
\text { regression }(\mathrm{rProb}>=\text { chibar } 2\end{array}$} & & 0 & 0 \\
\hline Observations & 241 & 241 & 241 & 241 \\
\hline R-squared & 0.5123 & 0.1115 & - & - \\
\hline
\end{tabular}

This table presents the effects of bank business models and other variables on bank rating level 2006 and bank rating difference between 2009 and 2006. See Sect. 4.3.1 for further details these models. Bank Rating CRAs 2006 is the mean of the numeric value of bank rating issued by the three agencies at the end of 2006 (Fitch, Moody's and S\&P). Section 3 explains the scale used to convert ratings into numbers. Traditional Income Ratio, our proxy of bank business models, is equal to: (Net interest income + fees and commissions - dividend income)/Op. income. See Table 1 for the definitions of other variables and Table 2 for summary statistics

$*, * *$ and $* * *$ Indicate statistical significance at the 10,5 and $1 \%$ levels respectively 


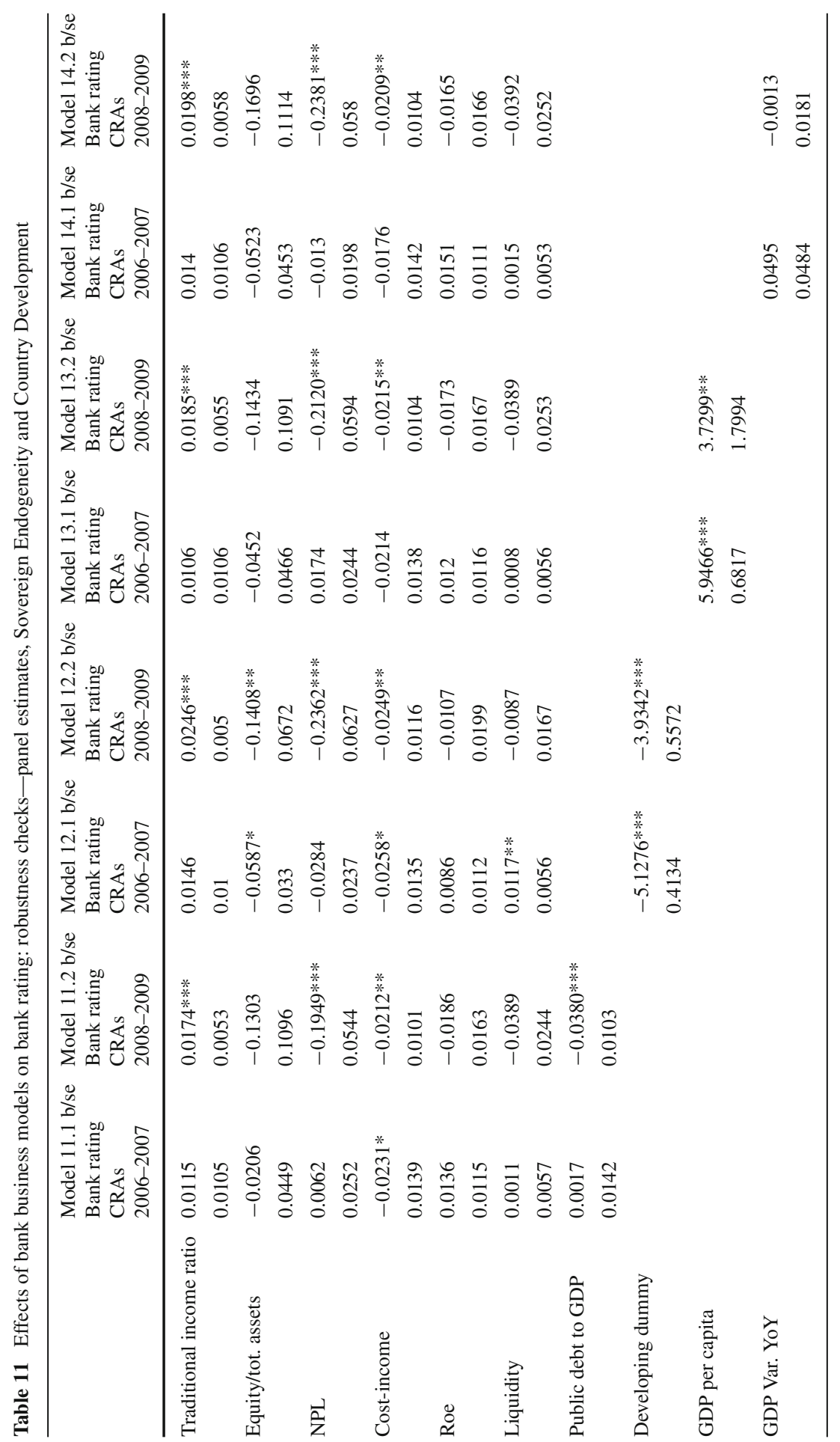




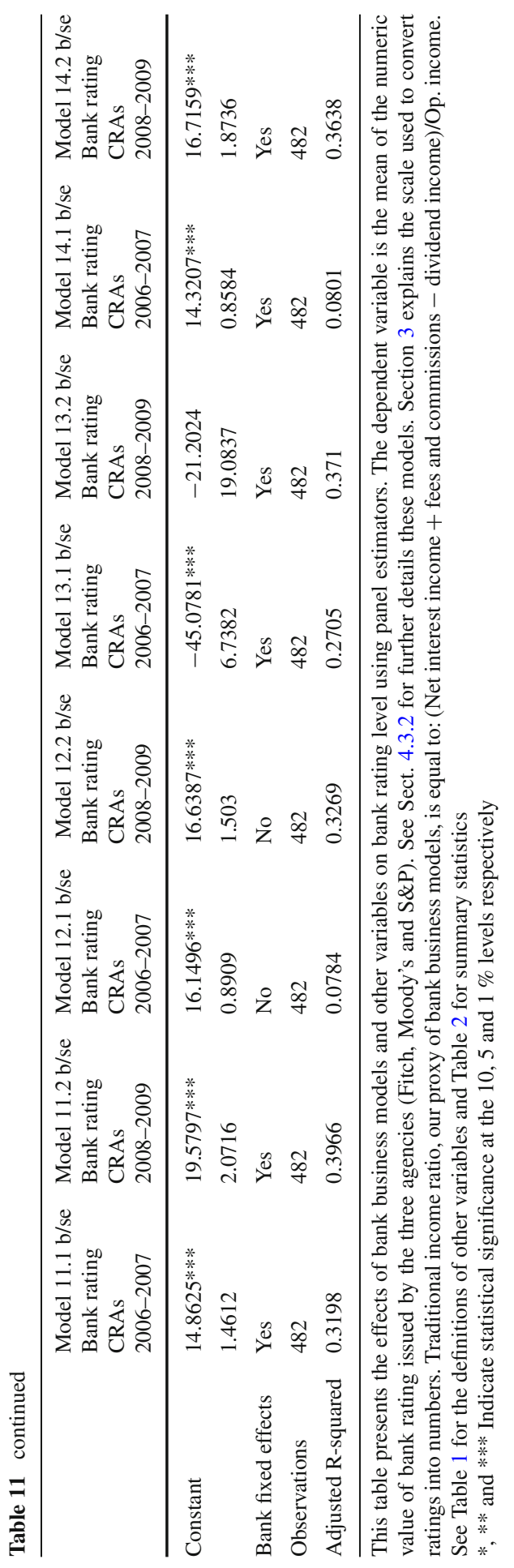




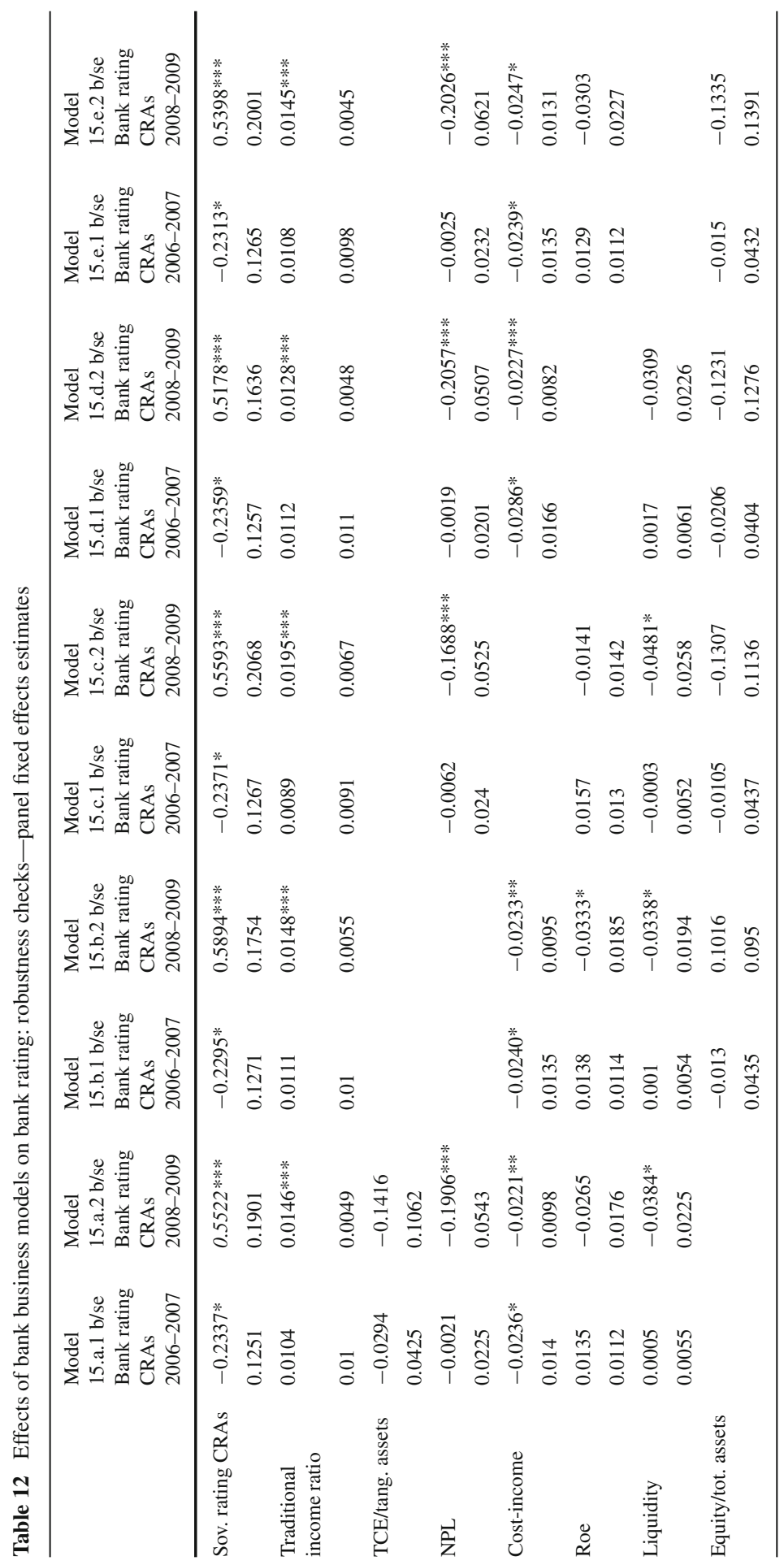




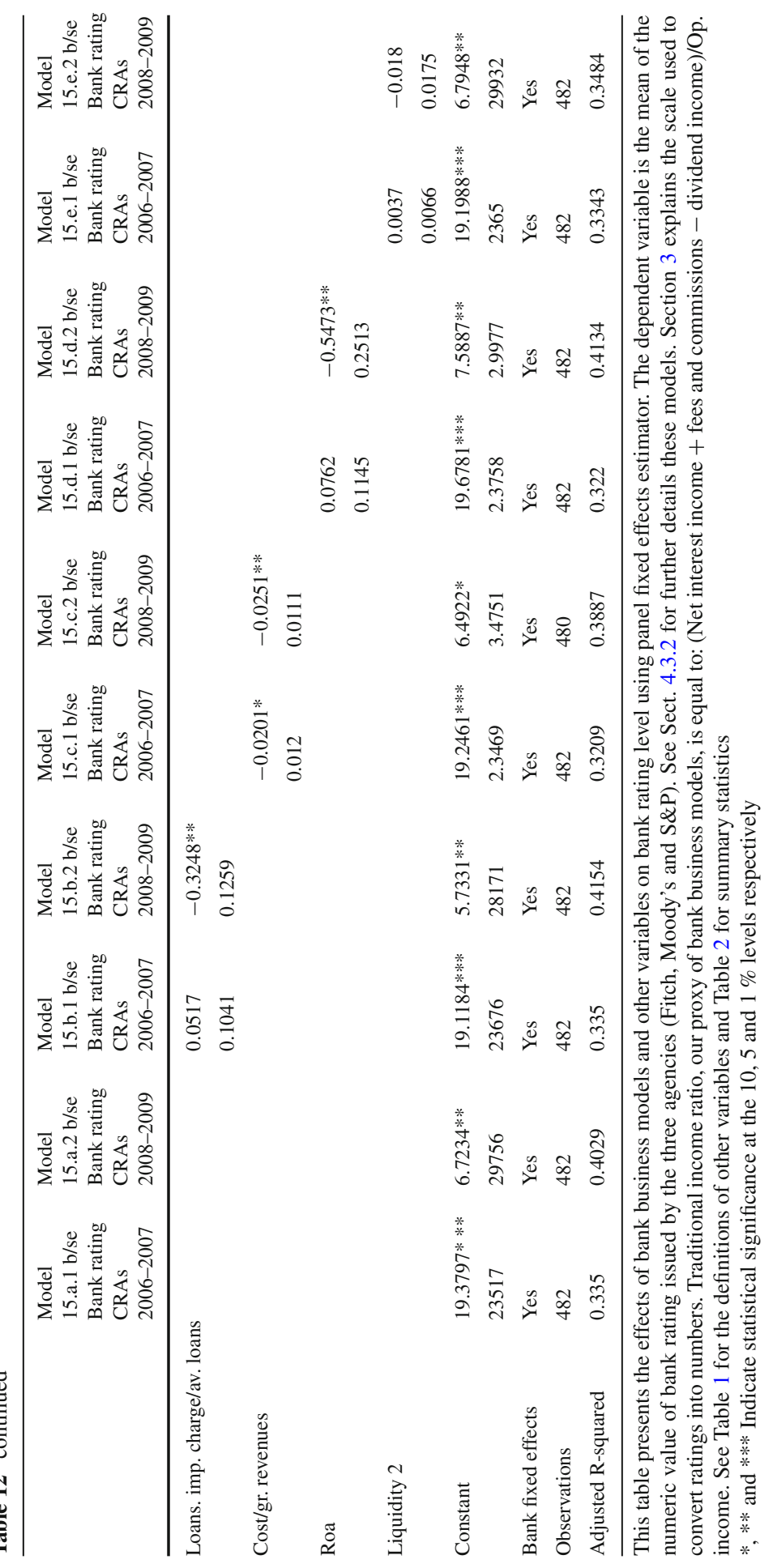


Table 13 Effects of bank business models on bank rating: panel fixed effects estimates based on full sample

\begin{tabular}{|c|c|c|c|c|}
\hline & $\begin{array}{l}\text { Model 16.a b/se } \\
\text { Bank rating CRAs }\end{array}$ & $\begin{array}{l}\text { Model } 16 . \mathrm{b} \text { b/se } \\
\text { Bank rating Fitch }\end{array}$ & $\begin{array}{l}\text { Model 16.c b/se } \\
\text { Bank rating Moody's }\end{array}$ & $\begin{array}{l}\text { Model 16.d b/se } \\
\text { Bank rating S\&P's }\end{array}$ \\
\hline \multirow[t]{2}{*}{ Sov. rating CRAs } & 0.1433 & & & \\
\hline & 0.1167 & & & \\
\hline \multirow[t]{2}{*}{ trad_inc_0607 } & -0.0026 & 0.0033 & 0.0026 & -0.0101 \\
\hline & 0.005 & 0.0048 & 0.0049 & 0.0101 \\
\hline \multirow[t]{2}{*}{ trad_inc_0809 } & $0.0212 * * *$ & $0.0218 * *$ & $0.0145 * * *$ & $0.0165^{*}$ \\
\hline & 0.0059 & 0.0088 & 0.0052 & 0.0099 \\
\hline \multirow[t]{2}{*}{ Equity/tot. assets } & -0.029 & 0.053 & 0.0146 & -0.1089 \\
\hline & 0.0803 & 0.0533 & 0.0619 & 0.08 \\
\hline \multirow[t]{2}{*}{ NPL } & $-0.1358 * * *$ & -0.0759 & $-0.1809^{* * * *}$ & $-0.1800 * * *$ \\
\hline & 0.0386 & 0.0487 & 0.045 & 0.0567 \\
\hline \multirow[t]{2}{*}{ Cost-income } & -0.0156 & -0.0067 & -0.0046 & $-0.0329 * *$ \\
\hline & 0.0123 & 0.0105 & 0.0052 & 0.0166 \\
\hline \multirow[t]{2}{*}{ Roe } & 0.0118 & $0.0288 * * *$ & 0.0116 & -0.0145 \\
\hline & 0.0123 & 0.0082 & 0.0075 & 0.0159 \\
\hline \multirow[t]{2}{*}{ Liquidity } & -0.0139 & $0.0163^{*}$ & 0.0092 & $-0.0245^{*}$ \\
\hline & 0.0158 & 0.0098 & 0.0078 & 0.0137 \\
\hline \multirow[t]{2}{*}{ y_06 } & $1.9965 * *$ & $1.5613 * *$ & 0.4537 & $2.6626^{* *}$ \\
\hline & 0.8314 & 0.6451 & 0.6281 & 1.0976 \\
\hline \multirow[t]{2}{*}{ y_07 } & $2.3830 * * *$ & $1.6040 * *$ & $1.3927 * *$ & $2.8486^{* *}$ \\
\hline & 0.835 & 0.6548 & 0.6169 & 1.0956 \\
\hline \multirow[t]{2}{*}{ y_08 } & $0.2202 * *$ & 0.1385 & $0.3380 * * *$ & $0.3273 * * *$ \\
\hline & 0.0893 & 0.1272 & 0.1074 & 0.077 \\
\hline \multirow[t]{2}{*}{ Sov. rating Fitch } & & $0.2928 *$ & & \\
\hline & & 0.1577 & & \\
\hline \multirow[t]{2}{*}{ Sov. rating Moodys } & & & 0.0315 & \\
\hline & & & 0.066 & \\
\hline \multirow[t]{2}{*}{ Sov. rating $\mathrm{S} \& \mathrm{P}$} & & & & $0.2156^{* *}$ \\
\hline & & & & 0.1014 \\
\hline \multirow[t]{2}{*}{ Constant } & $11.5545 * * *$ & $6.6828 * *$ & $13.7993 * * *$ & $12.8961 * * *$ \\
\hline & 2.2698 & 3.0068 & 1.4167 & 2.184 \\
\hline Observations & 964 & 717 & 685 & 580 \\
\hline Bank fixed effects & yes & yes & yes & yes \\
\hline Adjusted R-squared & 0.3119 & 0.3334 & 0.2999 & 0.3835 \\
\hline
\end{tabular}

This table presents the effects of bank business models and other variables on bank rating level using panel fixed effects estimator. In the first column the dependent variable is the mean of the numeric value of bank rating issued by the three agencies (Fitch, Moody's and S\&P). See Sect. 4.3.2 for further details on these models. Section 3 explains the scale used to convert ratings into numbers. Traditional income ratio, our proxy of bank business models, is equal to: (Net interest income + fees and commissions - dividend income)/Op. income. See Table 1 for the definitions of other variables and Table 2 for summary statistics $*, * *$ and $* * *$ Indicate statistical significance at the 10,5 and $1 \%$ levels respectively 


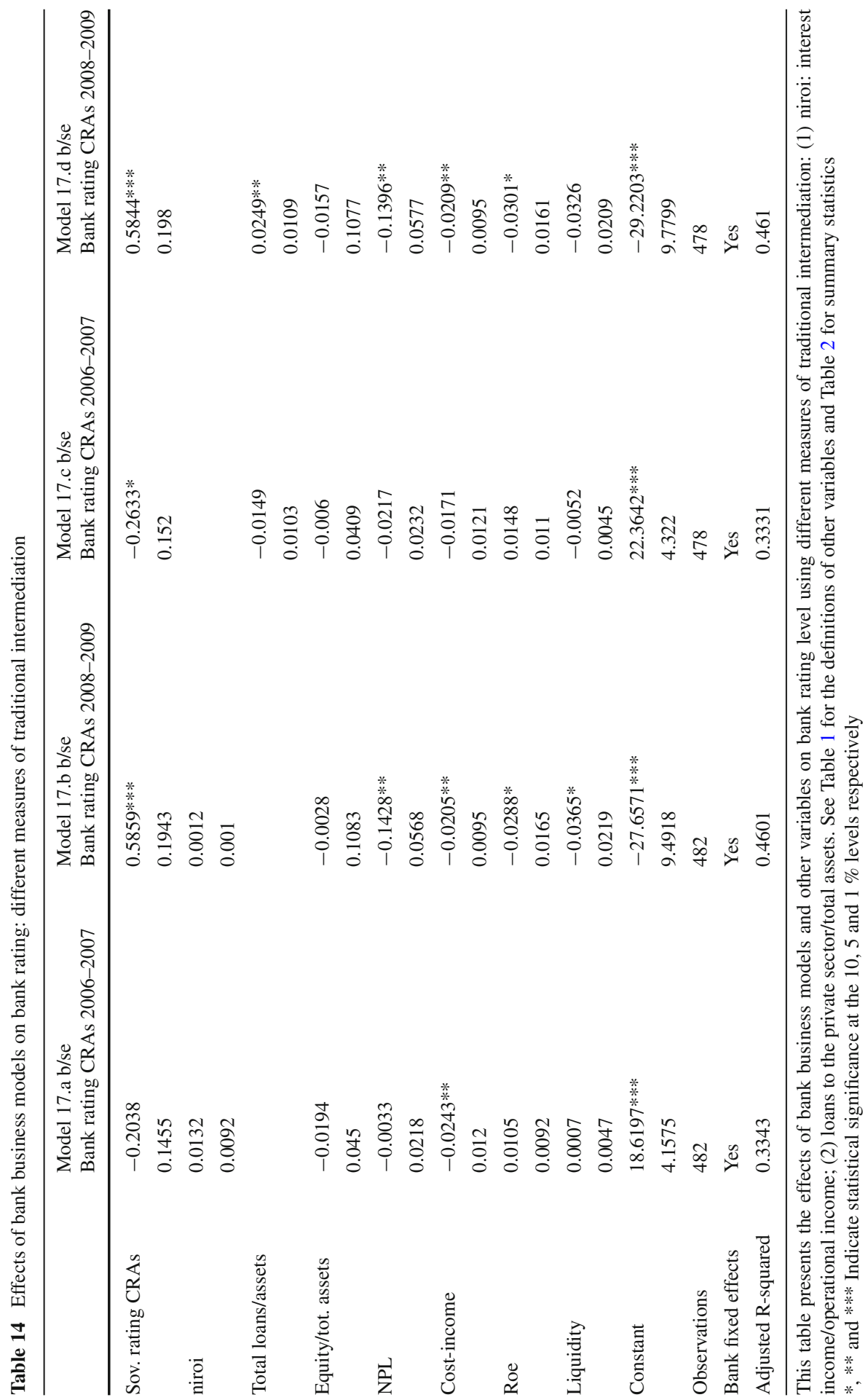


(Table 13, row 2) while the relationship between the two variables becomes positive and significant in 2008 and 2009 (Table 13, row 3). Moreover, this result holds for the mean ratings as well as for each of the three agencies (Table 13, columns 2, 3 and 4).

\subsubsection{Different Measures of Traditional Intermediation}

In this section we check if different measures of traditional intermediation can change the results.

As explained, in the base model we used the sum on interest income plus fees and commissions over operating income. Thus, as first check we use an index without the fees and commissions in the numerator:

Niroi: interest incomeloperational income

As second check, we proxy a traditional bank with the ratio of loans to the private sector on total assets.

As can be seen in Table 14, the niroi variable is significant in none of the periods. ${ }^{15}$ This result highlights the growing importance of fees and commissions also relating to traditional operations. ${ }^{16}$

Using the ratio of total loans over total assets does not change our results qualitatively. Thus, we are confirmed in sticking to trad_inc, which seems to provide a better proxy as highlighted also by the relevant literature.

\section{Conclusions}

We studied whether the main rating agencies-Fitch, Moody's and S\&P's—value banks' business model in defining individual ratings and whether that changed with the 2007-2009 crisis. Banks venturing out of their traditional credit intermediation domain into the trendy field of financial market dealings is perceived as one of the key culprits behind excessive pre-crisis lending. We suspected that before the crisis the rating agencies hardly appreciated traditional banking. So, evidence of a better rating performance for traditional banks would be a true route change and mean that markets_-via the agencies_-might in a way be on a self-correction path.

To test our hypothesis we compiled data for 241 listed banks from Europe, America and Asia. We improved upon previous studies by introducing a new measure of "traditional business" encompassing both non-interest income and fee income related to banks' credit intermediation function, in the spirit of De Young and Torna (2013). We studied bank ratings assigned by the three main agencies both in the end of 2006 cross section and in their subsequent changes until the end of 2009. While no significant relationship emerges in the 2006 cross section, we find a striking, statistically signif-

15 It is worth noting that if we were to replace trad_inc with niroi in the cross-section approach of the first part of the paper, niroi would turn out negative and significant for the bank ratings issued in 2006, while niroi would not significantly impact the change in the bank ratings between 2006 and 2009. Results available upon request.

16 As shown in Table 2, trad_inc has a higher mean value and a lower SD than niroi. Hence, the former has become a more important and more reliable indicator over time. 
icant and positive effect of the measure of traditional banking on individual banks' rating performance over 2006-2009. These results attain in the presence of various control variables and survive several robustness checks. This suggests a significant change through the crisis in rating agencies' assessment of the contribution of the traditional business model to bank stability.

Our findings are consistent with those obtained by Ferri et al. (2014) for rating performance of European banks across ownership/organizational structures. Contrasting "shareholder value" (profit maximizing) banks vs. "stakeholder value" (maximizing a wider objective, not just profit) banks they find that the rating performance between end 2006 and end 2011 was somewhat better for the latter banks. Differently from us, they focus on another definition of the ratings-Fitch and Moody's ratings on the financial strength of individual banks, i.e. excluding external support-and do not study explicitly individual banks' adherence to traditional business. In spite of that, their results are close to ours since stakeholder banks have remained much more traditional than their shareholder homologues.

Our results bear implications for financial regulation. First, if markets appear to value traditional banking, why are authorities still focusing on rules_-e.g., Basel IIIthat apply standardized calculations of risk and disregard factoring in banks' business model $?^{17}$ Second, if the business model is so crucial, there may be significant implications for the "level the playing field" approach taken by regulators and lawmakers. In fact, nominally identical credit risks can hide profound differences between two banks relying on the OtD vs. OtH models. Third, if a multiplicity of business models is perceived as a plus also in banking (Ayadi et al. 2012), maybe there is food for thought on the possibly unintended consequences of the era of banking deregulation that for decades tended to debase biodiversity in banking.

\section{References}

Acharya VV, Gujral I, Shin HS (2009) Dividends and bank capital in the financial crisis of 2007-2009. NBER working paper no 16896

Altunbas Y, Manganelli S, Marques-Ibanez D (2011) Bank Risk During the Financial Crisis. Do Business Models Matter? ECB working paper no 1394

Ayadi R, Arbak E, De Groen WP (2012) Regulation of European banks and business models: towards a new paradigm? Brussels, CEPS

Baele L, Van der Vennet R, Van Landschoot A (2004) Bank risk strategies and cyclical in bank stock returns. Gent University, Faculty of Economics working paper 2004/17

Baele L, de Jonghe O, Van der Vennet R (2007) Does the stock market value bank diversification? J Bank Financ 31:1999-2023

Benmelech E, Dlugosz J (2009) The Alchemy of CDO Credit Ratings. J Monet Econ 56(5):617-634

Berger A, Mester L (1997) Inside the black box: what explains differences in the efficiencies of financial institutions? J Bank Financ 21(7):895-947

17 To be fair, we should mention that in the Eurozone case the recent Supervisory Review and Evaluation Process (SREP) of the European Central Bank introduced a business model classification tool to conduct peer group analysis, which is leading to quantify additional prudential requirements (Pillar 2) for each bank. Though this looks to us a move in the right direction, it is only a tiny start. Bank business models analysis should be strengthened at supervisors leading to a better understanding of the different types of intermediation the various banks make, thus generating different types of risks. And it is difficult to think that business models will have a true bearing until the bulk of the banks' capital requirements are determined along the Risk Weighted Asset approach of Basel 2 and now of Basel 3. 
Berger, A, Mester L (1999) What explains the dramatic changes in cost and profit performance of the U.S. Banking industry? Federal Reserve Bank of Philadelphia working paper n. 99-01

Berndt A, Gupta A (2009) Moral hazard and adverse selection in the originate-to-distribute model of bank credit. J Monet Econ 56:725-743

BIS (2008) Some reflections on the future of the originate-to-distribute model in the context of the current financial turmoil. Speech by M.D. Knight, BIS General Manager, at the Euro 50 Group Roundtable on "The future of the originate and distribute model", London, 21 April 2008

Bongini P, Ferri G, Lacitignola P (2009) Was there a "small-bank" anomaly in the subprime crisis? In: Bracchi G, Masciandaro D (eds) Le banche italiane tra crisi finanziaria, tutela del risparmio e sviluppo produttivo. Bancaria, Rome

Bord VM, Santos JAC (2012) The rise of the originate-to-distribute model and the role of banks in financial intermediation. FRBNY Econ Policy Rev, July

Borensztein E, Cowan K, Valenzuela P (2013) Sovereign ceilings "Lite"? The impact of sovereign ratings on corporate ratings in emerging market economies. J Bank Financ 37(11):4014-4024

Cameron CA, Trivedi PK (2009) Microeconometrics using Stata. Stata Press, College Station (Texas)

Caporale GM, Matousek R, Stewart C (2011) EU banks rating assignments: is there heterogeneity between new and old member countries? Rev Int Econ 19(1):189-206

Caporale GM, Matousek R, Stewart C (2012) Ratings assignments: lessons from international banks. J Int Money Financ 31(6):1593-1606

Caprio G Jr, D’Apice V, Ferri G, Puopolo GW (2014) Macro financial determinants of the great financial crisis: implications for financial regulation. J Bank Financ 44:114-129

Coval J, Jurek J, Stafford E (2009) The economics of structured finance. J Econ Perspect 23(1):3-25

D'Apice V, Ferri G (2010) Financial Instability: Toolkit for Interpreting Boom and Bust Cycle. Palgrave Macmillan Studies in Banking and Financial Institutions, London

DeJonghe O (2010) Back to the basics in banking? A micro-analysis of banking system stability. J Financ intermediation 19:387-417

De Nicolo G, Bartholomew P, Zaman J, Zephirin M (2004) Bank consolidation, internationalization and conglomeration: trends and implications for financial risk. Financ Mark Inst Instrum 13(4):173-217

De Young R, Torna G (2013) Nontraditional banking activities and bank failures during the financial crisis. J Financ Intermediation 22(3):397-421

De Young R, Roland KP (1999) Product mix and earnings volatility at commercial banks: evidence from a degree of leverage model. Federal Reserve Bank of Chicago, working paper 99-6

Estrella A, Schich S (2012) Sovereign and banking sector debt: Interconnections through guarantees. OECD J Financ Mark Trends 2011(2):21-45

Ferri G (2004) More analysts, better ratings: do rating agencies invest enough in less developed countries? J Appl Econ 7(1):77-98

Ferri G, Kalmi P, Kerola E (2014) Organizational structure and exposure to crisis among European banks: evidence from rating changes. J Entrep Organ Divers 3(1):35-55. Retrieved from http://www. jeodonline.com

Ferri G, Liu L (2003) How do global credit-rating agencies rate firms from developing countries? Asian Econ Pap 2(3):30-56

Ferri G, Liu L, Majnoni G (2001) The role of rating agency assessments in less developed countries: impact of the proposed basel guidelines. J Bank Financ 25(1):115-148

Financial Services Authority, FSA (2009) The turner review: a regulatory response to the global banking crisis

Gallo J, Apilado V, Kolari J (1996) Commercial bank mutual fund activities: implications for bank risk and profitability. J Bank Financ 20(10):1775-1791

Gennaioli N, Shleifer A, Vishny R (2012) Neglected risks, financial innovation, and financial fragility. J Financ Econ 104:452-468

Harker P, Zenios S (2000) Performance of financial institutions. Cambridge University Press, Cambridge

Herring RJ, Santomero AM (1990) The corporate structure of financial conglomerates. J Financ Serv Res 4(4):471-497

Köhler M (2015) Which banks are more risky? The impact of business models on bank stability. J Financ Stab 16:195-212

Llewellyn DT (1999) The new economics of banking. SUERF studies n. 5

Mian A, Sufi A (2009) The consequences of mortgage credit expansion: evidence from the U.S. mortgage default crisis. Q J Econ 124:1449-1496 
Myers SC (1977) Determinants of corporate borrowing. J Financ Econ 5:147-175

Mercieca S, Schaeck K, Wolfe S (2007) Small European banks: benefits from diversification? J Bank Financ 31:1975-1998

Moody's Investor Service (2012) Proposed refinements to the sovereign bond rating methodology

Nickell P, Perraudin W, Varotto S (2000) Stability of rating transitions. J Bank Financ 24(1):203-227

Pagano M, Volpin PF (2012) Securitization, transparency and liquidity. Rev Financ Stud 25(8):2417-2453

Roland KP (1997) Profit Persistence in Large US. Bank Holding Companies: an empirical Investigation. Office of the Comptroller of the Currency, Economics working paper 97-2

Salvador C, Pastor JM, de Guevara JF (2014a) Impact of the subprime crisis on bank ratings: the effect of the hardening of rating policies and worsening of solvency. J Financ Stab 11:13-31

Salvador C, Pastor JM, de Guevara JF (2014b) The adjustment of bank ratings in the financial crisis: International evidence. Fundación de las Cajas de Ahorros, Documento De Trabajo N. 750/2014

Skreta V, Veldkamp L (2009) Rating shopping and asset complexity: a theory of ratings inflation. J Monet Econ 56(5):678-695

Staikouras C, Wood G, Denney R (2000) Bank Non-Interest Income: a source of stability? City University London working paper series. Retrieved from http://papers.ssrn.com

Staikouras C, Wood G (2003) Non-interest income and total income stability. Bank of England working paper n. 98

Stiglitz JE (2010) Freefall: America, free markets, and the sinking of the World Economy. WW Norton \& Company, New York

Stiroh KJ (2004) Diversification in banking: is noninterest income the answer? J Money Credit Bank $36(5): 853-882$

Stiroh KJ (2006) A portfolio view of banking with interest and noninterest activities. J Money Credit Bank 38:1351-1362 